\title{
Article \\ Beyond Reception History: The Qur'anic Intervention into the Late Antique Discourse about the Origin of Evil
}

\author{
Angelika Neuwirth * and Dirk Hartwig
}

check for updates

Citation: Neuwirth, Angelika, and Dirk Hartwig. 2021. Beyond Reception History: The Qur'anic Intervention into the Late Antique Discourse about the Origin of Evil. Religions 12: 606. https://doi.org/ 10.3390/rel12080606

Academic Editor: Roberto Tottol

Received: 24 May 2021

Accepted: 13 July 2021

Published: 4 August 2021

Publisher's Note: MDPI stays neutral with regard to jurisdictional claims in published maps and institutional affiliations.

Copyright: () 2021 by the authors. Licensee MDPI, Basel, Switzerland. This article is an open access article distributed under the terms and conditions of the Creative Commons Attribution (CC BY) license (https:// creativecommons.org/licenses/by/ $4.0 /)$.
Corpus Coranicum, Berlin-Brandenburg Academy of Sciences, 14467 Potsdam, Germany; hartwig@bbaw.de

* Correspondence: angelikaneuwirth@hotmail.com

\begin{abstract}
The article advocates a new approach to the Qur'an: To look at the text as a transcript of the earliest community's intervention into major debates of its time. Rather than earlier textual traditions ("reception history"), particular burning theological questions that were en vogue in the epistemic space of Late Antiquity are identified as the essential trigger of particular Qur'anic proclamations. Thus, the new - Late Antique-perception of evil (epistemic troubles experienced in the innermost selves of individuals - which cropped up during the sectarian strife in Middle Mecca) is etiologically explained through the primordial rebellion of Diabolos/Iblīs. This figure is portrayed in the Qur'an as a daring "dissenter in heaven" - a dignity that he had proven in various Biblical contexts (Book of Job, Gospels, etc.) before. His main characteristic is his eloquence and logical reasoning, which has earned him the epithet of the "inventor of qiyās/syllogism" in later Islamic tradition. His Qur'anic development is projected against the backdrop of rabbinic, patristic, and poetic exegeses, which together attest the vitality of a most diversified "epistemic space of Late Antiquity".
\end{abstract}

Keywords: Iblīs; Satan; origin of evil; reception history; intertextuality; 'initial sin'; good/evil inclination; first Adam/second Adam; Davidic kingdom; Late Antiquity

A particularly rewarding field of Qur'anic Studies that has yet not met with due attention is the Qur'an's dealing with universal problems shared by the monotheistic religions, where the Qur'an, however, follows a path of its own, offering substantially new perspectives. In view of the fact that Qur'anic theology has been sidelined over long periods of history, a re-evaluation of such discourses promises not only to increase our Qur'an knowledge but will also eventually encourage a theological rethinking within the two older religions that have shaped our European universe of knowledge. One such discourse is the origin and development of the concept of evil, embodied both in moral faults and in personally perceived psychic disturbances - a problem fervently debated in Late Antiquity and duly reconsidered in Jewish and Christian Studies. Contrarily, its Qur'anic manifestation - in the oft-repeated narrative of "Iblīs' Fall" - has not been explored in a comparably systematic way.

The ambiguous status of evil either as part of God's creational intent or, on the contrary, as due to a rebellion against his authority, is part of a universal quest, which reaches back into the very beginning of religious thinking in both the East and the West. The personification of primordial evil, moreover, Satan or Diabolos, "the devil", has occupied the minds of artists and literati in both the Western world (Greenblatt 2017; Flasch 2015) and in Islamic culture (Awn 1983) until present day, while brought to the fore as an object of theological controversy time and again (Haag [1969] 2000, 1974). Satan was adopted in secular thinking as a personification of intellectual, indeed political challenge in the Modern West and Middle East alike. ${ }^{1}$

The universal-'trans-disciplinary' - status of the problematic is also reflected in modern Late Antiquity scholarship where, more recently, Satan narratives of different origin (Pagels 1995; Grypeou and Spurling 2013) are being studied in context; occasionally including Islamic developments (Minov 2015; Reynolds 2006, pp. 71-83; Reynolds 2010, pp. 39-54). The new interest is partly due to more recently discovered (Pagels 1995, and 
others) textual sources and moreover to newly re-considered texts such as some long-time marginalized Old Testament Apocrypha (see Kaiser 2000; Rost 1985) that are concerned with the discourse of evil.

It is one of these apocrypha, whose plot lies at the basis of the particularly intricate Qur'anic story to be discussed in this contribution: The rebellion and "Fall of Diabolos/Iblīs". This story, which is extraordinarily prominent in the Qur'an, being told there no less than seven times ${ }^{2}$, provides an etiology of the phenomenon of evil strikingly different from the understanding(s) of the origin of evil that have come to prevail in Western cultures. According to the Qur'anic message-and in tune with some extra-Qur'anic Late Antique speculations-evil is not exclusively due to moral shortcomings ${ }^{3}$ but rather to wrong epistemic options. It is therefore worth studying not only in terms of reception history, as a random part of the multifaceted Levantine universe of knowledge, but as a genuine new cast of the image of "evil" and thus an essential part of culture in general.

\section{Major Tenets of the Article}

To expound this thesis, the article proposes a new approach to the Qur'an, to be exemplified by a discussion of the Diabolos/Iblīs-pericopes: To look closely at the Qur'anic presentation itself and screen it for its key questions before relating it to a specific Christian or Jewish predecessor. We proceed from the imagination not of textual layers horizontally packed one on the other, the older, lower, conditioning the younger, but rather from the image of an open epistemic space in which certain basic questions are being debated on eye-level. Though these questions may have been inspired by current theological convictions (that are of course worth identifying), we prioritize the quest for the more universal challenges, those aporias that loom behind the plots as such. ${ }^{4}$ The Qur'anic testimonies will be viewed as Late Antique expressions of the Diabolos/Satan discourse less indicative of particular confessionally determined predecessors than of the existence of a broader epistemic space, a "Denkraum" (Schmid et al. 2016). In this epistemic space, the predicament of man suffering after his expulsion from paradise has acquired new psychological dimensions that do not figure in the "antique", Biblical, account of the primordial couple's punishment, dimensions that are due to the shift of focus from divinely staged 'events' to processes that occur in the inner selves of men. To elucidate the novelty of this shift, a number of antique and Late Antique testimonies need to be discussed.

A further pre-supposition concerns the literary character of the Qur'an, which was not initially intended as a text corpus, but which still mirrors its earliest function as the transcript of a prophetic proclamation where basic ideas are unfolded successively. They do not enter the text at random times but can be shown embedded in particular social, political, or ideological debates arising from the perception of various real crises that can be determined by means of a diachronic reading of the Qur'an ${ }^{5}$. Thus, the debate about Adam and Satan/Diabolos can be related to a particular social setting, a Sitz im Leben that is reflected in middle Meccan suras; it arises from a social crisis, the situation of sectarian strife between believers in the message and opponents, adversaries that entertain doubts in the divine order. This social malaise is to be blamed on demonic forces, identified with "the hosts/offspring of Diabolos"/dhurriyyat Iblīs (Q 18:50) who dispose of attractive lures: Social privileges (Q 17:84) that the opponent group indeed boasts of. Their stance can thus be etiologically explained as due to demonic seduction. References to Satan/Diabolos/Iblīs indeed do not appear before the first "Iblīs sura", sūrat al-Hijr, Q 15 (early Middle Mecca), a sura that marks an intra-communal turn toward a new consciousness of the believers. ${ }^{6}$

\section{Specific Targets}

Though our topic is ultimately rooted in the Biblical creation and transgression narratives, it shifts the focus from the figure of Adam (and Eve) whose sojourn and expulsion from paradise has been discussed extensively in theology, to a rather ambiguous, outsider figure who is only foreshadowed in the Biblical story: Satan/Diabolos/Iblìs. Un- 
like the authors of recent studies in Genesis and its exegesis (Grypeou and Spurling 2013; Minov 2015) or in the Qur'anic reading of essential Genesis periscopes (Reynolds 2006; Pregill 2020), we are less interested in dependencies between individual testimonies, than in the scriptural genealogy of Satan/Diabolos/Qur'anic Iblīs to illuminate the significance of the type of "dissenter" that this figure represents in Late Antique thinking. It is Iblīs' story, his refusal to venerate Adam, and thus his Fall, that in the Qur'an has theologically eclipsed the Biblical narrative about the primordial couple's transgression and thus Adam's Fall, a shift of focus that blots out the theologumenon of the 'initial sin' as a stain superincumbent on mankind as such. In the Qur'an, it is Iblīs who bears the brunt of the introduction of evil into the world. His transgression is not a physical act, but an act of speech that contradicts a divine ruling. While his activity in heaven is daring, but not wrong in itself, even accepted by God, he and his hosts after their expulsion from the vicinity of God mutate into a much-maligned agency, the "hosts of demons", al-shayātìn, that - in Late Antique thought-assault and torment humans.

In the early Qur'anic perception, laid down in the Middle Meccan suras (See Neuwirth 2017; Neuwirth and Hartwig 2021), this demonic intervention targets a particular group of humans: The rich and privileged who are prone to be "seduced", who for the sake of their social comforts turn their backs to the divine guidance. At a later stage, the demons' activity becomes ubiquitous, therefore believers need to be equipped with devices to ward them off, such as apotropaic formulas.

Our shift of interest from the morally heavily charged figure of Adam to the lighthanded, inquisitive Diabolos pays tribute to the crucial turn in the reception of the past that occurred in Late Antiquity when canonical traditions of "antiquity", not least the Hebrew Bible, were re-read and often reversed. It is such a reversal of a Biblical story that can be observed in Diabolos' case: His replacing Adam as the central figure in the discourse of evil/sin. Adam's transgression in the "antique" Biblical view had been requited with his expulsion from paradise, his loss of immortality, and his exposure to various kinds of hardship. In Late Antiquity, however, the human malaise on earth is perceived no longer in man's loss of bliss but located in an essentially different realm: The epistemic - where the divine order itself has become a matter of controversy. ${ }^{7}$

In Section I of this article, the figure of Diabolos/Iblīs, the dissenter angel, will be reembedded in his scriptural genealogy and distinctly profiled through the projection of rivalling narrative traditions available in the "epistemic space" of Late Antiquity. This will allow us to define the peculiar epistemic nature of the evil originated by him. While Iblīs in the Qur'an has eclipsed, even replaced Adam as the initiator of evil in the world, in the neighboring religions, debates about the origin of evil rooted in Adam's transgression abound. These need to be noted to illuminate the epistemic space from which the Qur'an emerges.

Section II is therefore concerned with the universe of debates about Iblīs' antagonist, Adam, whose privileged status as created in the image of God aroused problems in both the Jewish and the Christian traditions. The diversity of the solutions offered-some of them resorting to Hellenist "scientific" models to explain evil psychologically-throws light on the wide range and depth of the attempts to cope with the ambiguous claim of the existence of an almost God-like being aside God, which in the Qur'anic narratives is excluded from the outset. This is a major issue of controversy in view of the messianic movements, which at the time of the Qur'anic proclamation, claim (or at least, debate) "a second power in heaven", 8 see below.

The challenge of the Iblīs-Adam antagonism eventually (Section III) leads to the generation of a new image of man. In Medina, where previous proclamations are frequently re-visited under novel political aspects, and where a new, optimist perspective on the human nature has evolved, Adam is re-habilitated. While the first man Adam's divinely decreed investiture into the rank of a ruler over all creatures in the Meccan Fall narratives had been jeopardized - a downgrading of Adam in tune with the pessimism vis-à-vis the human nature that had for long time prevailed in Mecca ${ }^{9}$ - in Medina, Adam is installed 
as a viceroy, khalīfa, of God on earth (al-Qādī 1988, pp. 392-411; Steppat 1989). His development is no simple reversal of the earlier story, however.

The new Adam is no longer the mythic Adam, but a symbolic figure covering humans in general, their moral ambiguity included. His promotion to the Davidic dignity to a God-pleasing eternal king, khalifa, known from Q 38:26 occurs in full consciousness of the prospective that moral evil will come forth from "Adam" who, once established as a ruler, will shed blood. Moral failure, which is part of the real world, into which the figure of Adam representing the collective of "mankind", now enters, is deemed tolerable evil-it is devoid of mythic dimensions. Yet, the "epistemic evil", in the sense of demonic temptations, generated by Iblīs' hosts, has not been abolished, and Iblīs' initial dissent is still remembered explicitly. The new political Adam, understood as the collective of men capable of governing the world, not only affirms the community's having come to age, but also responds to the claims of ideological movements of the time: The new "universal" Adam at once eclipses the individual "utopian David" of the contemporary Jews and the "second Adam", the yet-to-come Christian redeemer figure. His election expresses immense confidence in humankind as such, which is in no need of mythic paragons. He ideally represents the new community, who has-seen from the new optimistic perspective-by now achieved a status sufficient to be accepted as a partner of God in the governance of the world (Neuwirth 2010, pp. 607-12 [English: pp. 375-78]) - a world in which demons will, however, continue their 'hermeneutic task', their challenging work of tempting men.

\section{Dissenters in Heaven, in Paradise, and on Earth}

\section{Adam}

\subsection{Apocryphal Traditions on Adam and the "Bible of the Folk"}

There are a number of biblical stories that in post-biblical times have been extended, 'complemented' so-to-say, by a "pre-history". Among the numerous apocryphal "testaments" or "apocalypses" ascribed to Biblical figures, such as Abraham, Moses, Job, and others, one text excels: The apocryphal Life of Adam and Eve (1st c. CE). ${ }^{10}$ It presents the myth of Diabolos' Fall (better known as "Satan's Fall"), though not for the sake of its narrative plot, but rather with a strong etiological intent: To complement the Biblical "history" of the creation of man, i.e., the first couple (Gen 1:26; Gen 2:18-25), and man's first transgression (Gen 3:1-24) with a history of the emergence of the demons. Though the text concentrates on events after the expulsion of the first couple from paradise, it does dwell in a flashback on the events prior to and immediately subsequent to Adam's creation, events that eventually led to the emergence of a demonic realm. The Life that presents the oldest unadorned narrative report about Diabolos' rebellion and Fall, a plot which in other texts is only referenced, deserves special attention. The plot itself should have been well known, thus major Pseudepigrapha allude to it and various New Testament texts typologically presuppose it. However, the Life is not only the oldest narrative representation, it is also the least biased one: It does not stand in the service of any particular theology, Jewish or Christian. ${ }^{11}$ It therefore deserves to be conceded a special status, to belong to the "Bible of the Folk" (Utley 1945). This category, introduced in anthropology, covers those Biblerelated traditions that-although not canonic-were ubiquitously known and considered authoritative. The "Fall story" indeed should be regarded as such a para-Biblical text.

The Life's story plot, however, became much more widespread in its Syriac Christian re-writing titled the "Cave of Treasures" (me ârath gazzê, 4th, 5th or 6th? c. CE) ${ }^{12}$, where the protological events are interpreted in blatantly Christological terms, culminating in a kind of apotheose of Adam. Though this lengthy and somewhat loquacious version has come to enjoy much attention among recent scholars, even occasionally regarded as a possible source for some Qur'anic features (Reynolds 2010, pp. 39-54), it is less significant for our purpose, since it has widely blurred the etiological dimensions of the protological discourse. 
The unadorned older story, however, entails much more than hagiographical information. It can be claimed to be a kind of prologue to the canonical Biblical creation story to explain the existence of that part of the created world, which had found no place in the canonical narrative: The demonic realm. The "Fall of Diabolos" story, for the first time expounded in the Life of Adam and Eve, gives expression to a new, particularly Late Antique, understanding of the world as inhabited not only by men, but by both humans and demons, a view that was to be debated in numerous later writings, ecclesiastical and rabbinical alike. It was equally to play a momentous role in the Qur'an.

\subsection{Creation and First Transgression}

The Biblical creation story celebrates the exquisite nature of Adam, who was created "in the image of God" (be-selem elohim) and who is destined to become installed as the ruler of the other creatures:

Genesis 1:26-27

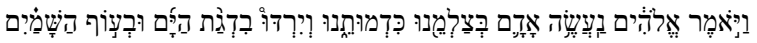

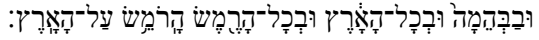

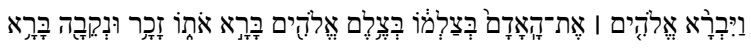

And God said, 'Let us make man in our image, after our likeness: and let them have dominion over the fish of the sea, and over the fowl of the air, and over the cattle, and over all the earth, and over every creeping thing that creepeth upon the earth'.

So God created man in his own image, in the image of God created he him; male and female created he them.

The divine statement is usually understood as referring exclusively to God himself. In the late antique reading, however, God's project to create man is not exclusively his own, but as the plural form "Let us make" indicates, is shared with others, according to rabbinic understanding with the angels ${ }^{13}$. It is one of these angels who will speak up and try to impede the full realization of the plan, which should imply Adams's recognition as the ruler over all creature, the angels and demons included, an aspect that is frequently discussed in exegetical writings (Schäfer 1975) and which is the trigger of the Diaboloscentered "counter history of creation". Diabolos refuses to acknowledge Adam and thus risks the failure of a substantial part of the divine project to establish Adam's rulership universally.

In the biblical story, the (partial) failure of the divine project is due to Adam himself. Adam's story goes on with his own first transgression. The primordial couple, though instructed by God to refrain from approaching a particular tree in paradise, ignores the ruling and thus brings about the first sin. The act is instigated by an evil creature that persuades Eve with convincing arguments to reject the prohibition. Adam's transgression is severely punished, it is requited with the humans' expulsion from paradise, their loss of immortality and their exposure to numerous kinds of hardship. It suffices here to quote the divine verdict:

The nature of this sin-whether a daring transgression or just a moral slip-has occupied the minds of readers for centuries, resulting in most momentous theological discrepancies (see below Section II). The even more vexing question, however, concerned the outcome of the event. Does man's expulsion from paradise, his loss of paradisiacal conditions of life, or even of immortality-does all this really suffice to account for the empirically perceived malaise of human life on earth? In Late Antiquity, the human malaise on earth is perceived not in man's tragical loss of bliss, but is located in an essentially different realm: The epistemic. What troubles individuals most is the perception that the divine order itself has become a matter of controversy. What is demanded is an etiological explanation of a more abstract evil such as prevails in moral aporias, irreconcilable antagonisms between prescriptions and desires, doubts in the binding force of divine rulings. The Qur'anic response to this Late Antique aporia is a shift in focus: The preference of a new symbolic figure: Diabolos/Iblis, the dissenter in heaven whose fate can explain the 
presence of psychologically vexing forms of evil, which the Biblical Fall story, focused on Adam, does not offer an explanation for.

Genesis 3:1-24

1

$[\ldots]$

6

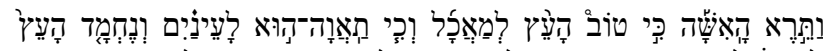

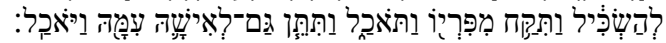

$[\ldots] \quad[\ldots$

9

10

11

12

$[\ldots]$

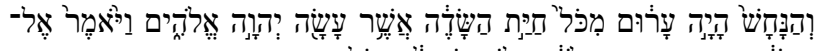

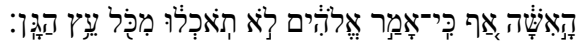

$[\ldots]$

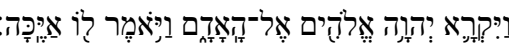

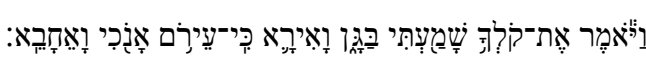

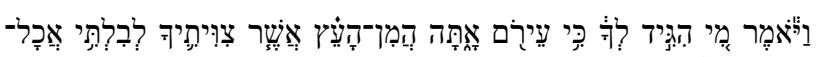

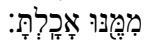

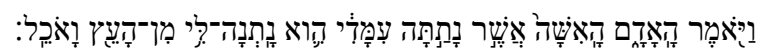

$[\ldots]$

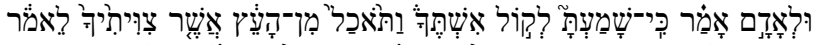

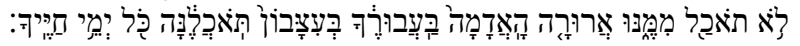

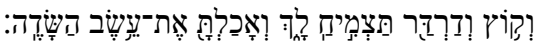

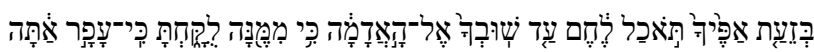

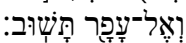

Now the serpent was more subtile than any beast of the field which the Lord God had made. And he said unto the woman, Yea, hath God said, Ye shall not eat of every tree of the garden?......

$[\ldots]$

[...] when the woman saw that the tree was good for food, and that it was pleasant to the eyes, and a tree to be desired to make one wise, she took of the fruit thereof, and did eat, and gave also unto her husband with her; and he did eat.

$[\ldots]$

And the Lord God called unto Adam, and said unto him, Where art thou?

And he said, I heard thy voice in the garden, and I was afraid, because I was naked; and I hid myself.

And he [God] said, Who told thee that thou wast naked? Hast thou eaten of the tree, whereof I commanded thee that thou shouldest not eat?

And the man said, The woman whom thou gavest to be with me, she gave me of the tree, and I did eat.

$[\ldots]$

[...] unto Adam he said, Because thou hast hearkened unto the voice of thy wife, and hast eaten of the tree, of which I commanded thee, saying, Thou shalt not eat of it: cursed is the ground for thy sake; in sorrow shalt thou eat of it all the days of thy life; Thorns also and thistles shall it bring forth to thee; and thou shalt eat the herb of the field;

In the sweat of thy face shalt thou eat bread, till thou return unto the ground; for out of it wast thou taken: for dust thou art, and unto dust shalt thou return.

\section{Diabolos (Satan/Diabolos/Iblīs)}

Late Antique thinking provides a kind of "pre-history" to the creation and transgression narrative in Gen 1-3. The story about the "Fall of Satan/Diabolos/Iblīs"14 is equally staged in the time of creation but features a figure who-in his capacity of a member of the heavenly assembly-dares to question a divine project. Adam, who is the object of the controversy, plays no active role here; he is thus a priori exempt from the verdict to have been the essential instrument in the emergence of evil for mankind. The story told here, which culminates in the mutation of the angel Diabolos to a demon, Satan, and the mutation of his heavenly hosts into a host of disturbing demonic agents is apt to explain the emergence of the demonic realm. It is not extant as a narrative of its own but is known from flash-backs extant in longer dramatical stories about Adam, most importantly the apocryphal The Life of Adam and. Eve, (1st c. CE). 


\subsection{Diabolos in the Apocryphal Life of Adam and Eve}

Et ingemescens diabolus dixit: $\mathrm{O}$ Adam, tota inimicitia mea et invidia et dolor ad te est, quoniam propter te expulsus sum et alienatus de gloria mea, quam habui in caelis in medio angelorum, et propter te eiectus sum in terram.... Quando tu plasmatus es, ego proiectus sum a facie dei et foras a societate angelorum missus sum. quando insufflavit deus spiritum vitae in te et factus est vultus et similitudo tua ad imaginem dei, et adduxit te Michahel et fecit te adorare in conspectu dei, et dixit dominus deus: ecce Adam, feci te ad imaginem et similitudinem nostrum. Et egressus Michahel vocavit omnes angelos dicens: adorate imaginem domini dei, sicut praecepit dominus deus. Et ipse Michahel primus adoravit, et vocavit me et dixit: adora imaginem dei Jehova. Et respondi ego: non habeo ego adorare Adam. et cum compelleret me Michahel adorare, dixi ad eum: quid me compellis? non adorabo deteriorem et posteriorem meum. in creatura illius prius sum. antequam ille fieret, ego iam factus eram. ille me debet adorare. Hoc audientes ceteri qui sub me erant angeli noluerunt adorare eum. Et ait Michahel: adora imaginem dei. si autem non adoraveris, irascetur tibi dominus deus. Et ego dixi: si irascitur mihi, ponam sedem meam super sidera caeli et ero similis altissimo. Et iratus est mihi dominus deus et misit me cum angelis meis foras de gloria nostra, et per tuam causam in hunc mundum expulsi sumus de habitationibus nostris et proiecti sumus in terram ${ }^{15}$.
And with a heavy sigh, Diabolos spake: 'O Adam! all my hostility, envy, and sorrow is for thee, since it is for thee that I have been expelled from my glory, which I possessed in the heavens in the midst of the angels and for thee was I cast out in the earth.' ... When you were formed I was expelled from the face of God and from the company of the angels. When God blew into you the spirit of life and your traits were formed in the image of God a Michael drove us to venerate you in the sight of God and the Lord God said: 'Adam. I created you in my image and likeness'. And Michael went out and called all the angels saying: 'Worship the image of God as the Lord God hath commanded.' And Michael himself worshipped first; then he called me and said: 'Worship the image of God the Lord.' And I answered, 'I have no (need) to worship Adam.' And since Michael kept urging me to worship, I said to him, 'Why dost thou urge me? I will not worship an inferior and younger being (than I). I am his senior in the Creation, before he was made was I already made. It is his duty to worship me.' When the angels, who were under me, heard this, they refused to worship him. And Michael saith, 'Worship the image of God, but if thou wilt not worship him, the Lord God will be wrath with thee.' And I said, 'If He be wrath with me, I will set my seat above the stars of heaven and will be like the Highest.' And God the Lord was wrath with me and banished me and my angels from our glory; and on thy account were we expelled from our abodes into this world and hurled on the earth.

\subsection{The Fall of Diabolos in the Cave of Treasures}

The popular work Cave of Treasures, an extended version of the Life, is heavily charged with Christian theologumena profiling Adam as God's elect created in his image who seems occasionally blended with Christ, the "second Adam". Since it shares some information with the Qur'an (God's creating man with his own hands, etc.), it has occasionally been claimed as a source for the Iblis stories that have therefore been imputed to express the belief of Adam's creation in the image of God (Reynolds 2010). The claim is, however, highly problematic, not only since some of the alleged similarities can be traced in rabbinic texts as well, but moreover because it contradicts the Qur'anic images of Adam, see below. A much broader epistemic space should therefore be assumed to form the framework for the Iblis stories than that of the Cavern, which displays a peculiar style of narrating, tending to loquacity and exaggeration. 


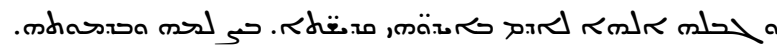

$[\ldots]$

21

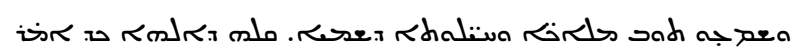
له لهהדק.

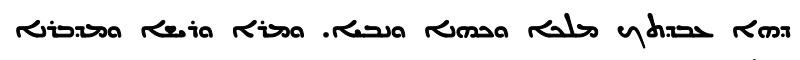

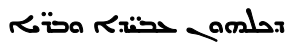

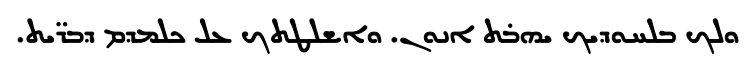

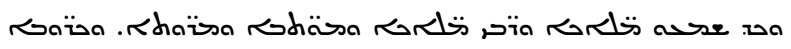

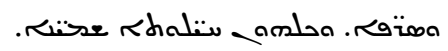

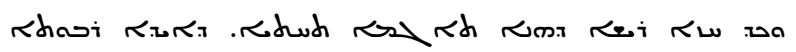

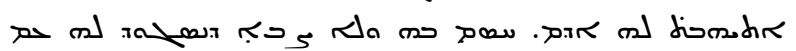

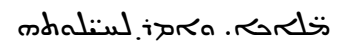

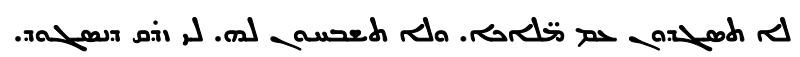

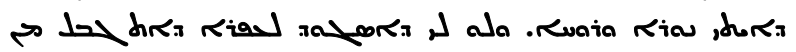

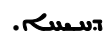

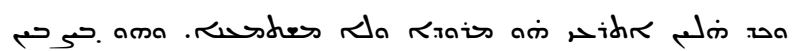
.

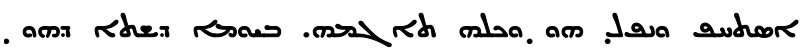
حiخ - andward, palder

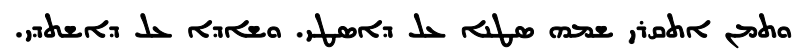

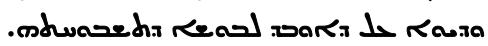

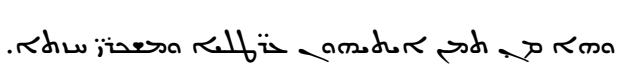

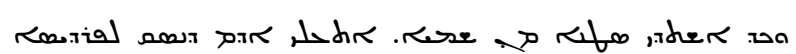

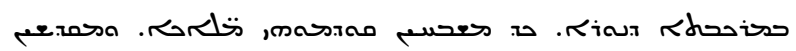

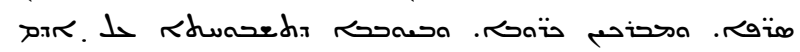
.rosial

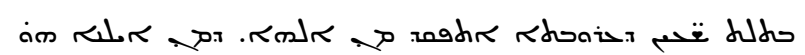

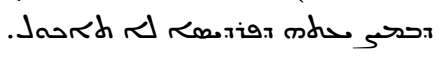

God formed Adam with his holy hand in his image according to his likeness.

$[\ldots]$

All beings worshipped him and submitted themselves before him.

Then the angels heard God's voice speaking to him:

"Adam, behold, I made you king, priest and prophet, lord, chief and leader, so that everything made and created may be subservient unto you and belong to you.

\section{To you I give dominion over every created thing."}

When the angels heard this heavenly voice they all bent their knees and worshipped him.

When the chief of that lowest rank saw what greatness had been bestowed upon Adam he envied him from this day on. He did not want to worship him and spoke to his army:

"Let us not worship and glorify him together with the angels. It is meet that he worships me who am fire and spirit and not that I worship dust formed from dirt."

As soon as the rebel conceived this and was disobedient as regards the wish of his soul and volition he separated himself from God.

He was cast down and fell, he and his whole rank, on Friday, the sixth day, and their fall from heaven lasted for three hours.

\section{The garments of their glory were taken from them}

and he was called "Satan" because he set himself apart, and "Sheda" because his glory had been shed and he had forfeited the garment of his glory.

Behold, since that day until now they are naked and bare and of despicable look, he and all his hosts.

When Satan had been cast down from heaven Adam was lifted up and ascended to paradise in a fiery chariot. Adam went up to paradise with praises, the angels glorifying him while the seraphs sang the Trisagion before him and blessed him.

Immediately after he had gone up he was commanded not to eat from the tree. His ascent to paradise took place in the third hour of Friday ${ }^{16}$

There is, however, one trait of Iblis' character that both the Life and the Cave share and which is inseparable from his role: His eloquence and convincing arguing. In the Life, he reasons: "I have no (need) to worship Adam. I will not worship an inferior and 
younger being (than I). I am his senior in the Creation, before he was made was I already made. It is his duty to worship me". In the Cave, he adduces the argument of his more subtle material of creation "Let us not worship and glorify him together with the angels. It is meet that he worships me who am fire and spirit and not that I worship dust formed from dirt." Both arguments are part of a more general Late Antique demonology ${ }^{17}$, The image the arguing demon itself has however a pristine genealogy. It is rooted in Biblical heritage, see below Section 2.4. This genealogy is acknowledged in Christian, though not in Jewish, tradition where the role of Diabolos is curtailed, and even a counter-scenario to Diabolos' intervention into ambiguous angelic worship of Adam has been developed.

\subsection{GenR 8:10: A Jewish Dealing with Improper Angelic Attitudes toward Adam-Staging God, Not Diabolos}

The Rabbis had their own view about the situation of Adam's peculiar and unforeseen appearance among the angels. In a well-known midrash relating to the event no prominent angelic agent occurs, the veto against the angels' Adam worship is voiced by God himself. Taking the incitation "let us make" as an implicit address to the angels, the Rabbis staged Adam's creation in their company. Far remote from disapproving of Adam's privileged status, let alone from objecting to it - the angels were highly impressed by his appearance so that they desired to venerate him as a deity. To avoid any further confusion, God himself had to correct their error. Adam's elimination from their sight is clad into a mashal, a parable: A king travels with his Eparch-a high official in the Roman/Byzantine hierarchy-in a chariot. When the citizens mistaking the Eparch for the king prepare to hail him with 'Domine', 'O Lord', the king resolutely pushes his Eparch out of the vehicle. Thus, no angelic agent to defend the unity of God against the angels' proneness to adore an "Eparch" is needed. The insight into the ambiguity - should a human created in the image of God be venerated - is claimed for God alone. The story may have arisen as an answer to the extraordinary dramatization of God's angelic counterpart Diabolos known from the apocryphal stories, but it may equally be a harsh response to the exaggerated valorization that Adam enjoys in Christian traditions, particularly in the Cave, which associates Adam with Christ, the 'second Adam'.

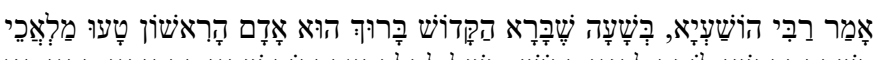

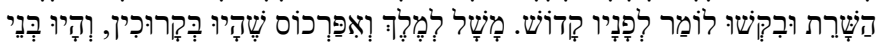

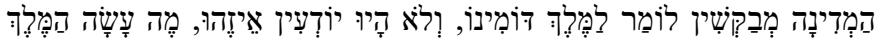

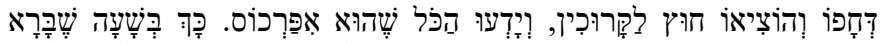

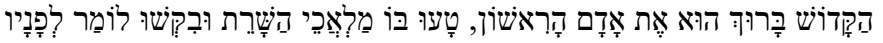

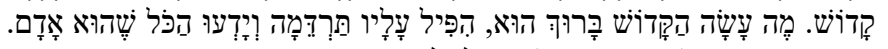

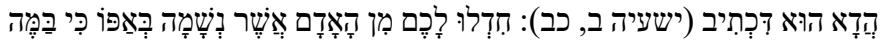

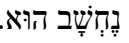

Rabbi Hoshaya said: When the Holy One, Blessed be He, created the first man/Adam, the Ministering Angels erred and wanted to utter the Qedusha before him. This may be compared to a king and his "Eparchos" that sat in a chariot/carruca (qarukhin). Now, the people of the kingdom wished to address the king with "Domine", but didn't know whom. So what did the king do? He shoved the Eparchos and pushed him down from the chariot, so that everyone knew that he was the "Eparchos". So too, when the Holy One, Blessed be He, created the first man/Adam, the Ministering Angels erred and wanted to utter the Qedusha before him. What did the Holy One, Blessed be He, do? He caused slumber to fall upon him (Gen 2:21) so everyone knew that he was man/Adam, as it is written: "Withdraw from man/Adam who has breath in his nostrils, for how little is he to be esteemed" (Is 2:22) ${ }^{18}$

The midrash and the Cave narrative share significant traits, most strikingly the use of the Qedusha/the Trishagion (Is 6:3) as the uttering of the angels in adoration of Adam 
(Cave 3:8). Another trait of the Cave should have been even more provocative, Adam's placement in a chariot, Cave 2:17. It is exactly from such a seat of honor that the midrashic Eparch is pushed down - an image that is hard to take simply pictorial. It might be a device to ridicule the 'enthroned' figure of the Cave. Seen in this way, the midrash would be a Christology-polemical story. It is, however, hard to ignore that the figure of the Eparch seated next to the king evokes messianic associations as well, that needed to be rejected by the Rabbis. Though the story is disinterested in the explanation of the emergence of the demonic realm, it is worth to be quoted here to illuminate the epistemic space into which the non-biblical figure of Diabolos intervenes - as an upright figure in the midst of idolatrous angels.

\subsection{The Biblical Genealogy of the 'Arguing Demon'}

The significance of the figure of Diabolos can thus hardly be overrated. It is no exaggeration to state that with his focusing, the point of the primordial transgression story has shifted from a moral to a hermeneutic discourse. It is easy to realize that the story of Diabolos' rebellion and his Fall relies on an essentially different scriptural memory from that of the Genesis story, namely, wisdom literature, particularly the Book of Job. The prologue of Job depicts a court scene, where an angelic advisor of God, a 'satan' - in Greek translation: 'Diabolos' - a kind of prosecutor in the divine court, receives the task to test one of God's elects, the just Job. The story allows for diverse interpretations. One often overlooked aspect is the ambiguity of the satan's task who is permitted to question the divine verdict on Job. It is this trait that qualifies him as a predecessor of the Late Antique Diabolos.

\subsubsection{Job}

1

$[\ldots]$

6

7

8

9

10

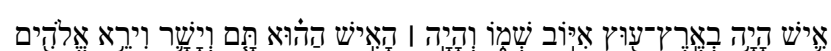

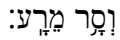

$[\ldots]$

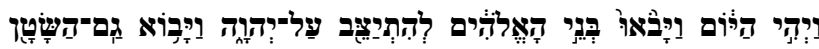

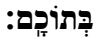

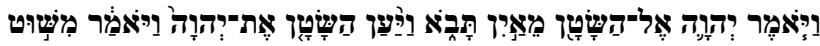

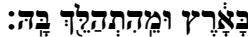

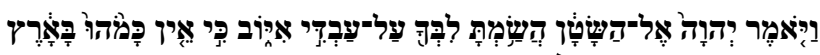

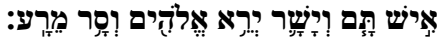

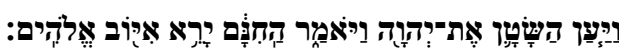

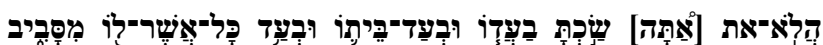

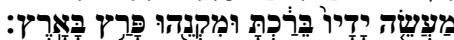

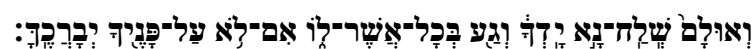

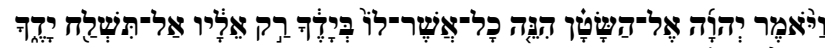

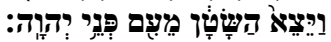

There was a man in the land of $\mathrm{Uz}$, whose name was Job; and that man was perfect and upright, and one that feared God, and eschewed evil.

[...]

Now there was a day when the sons of God came to present themselves before the Lord, and the Satan came also among them.

And the Lord said unto the Satan, Whence comest thou? Then the Satan answered the Lord, and said, From going to and fro in the earth, and from walking up and down in it.

And the Lord said unto the Satan, Hast thou considered my servant Job, that there is none like him in the earth, a perfect and an upright man, one that feareth God, and escheweth evil?

Then the Satan answered the Lord, and said, Doth Job fear God for nought?

Hast not thou made an hedge about him, and about his house, and about all that he hath on every side? thou hast blessed the work of his hands, and his substance is increased in the land.

But put forth thine hand now, and touch all that he hath, and he will curse thee to thy face.

And the Lord said unto the Satan, Behold, all that he hath is in thy power; only upon himself put not forth thine hand. So the Satan went forth from the presence of the Lord. 


\subsubsection{Ephrem's De Paradiso XII:11-12: A Late Antique Valorization of Job's Satan}

The figure of the Satan; ha-satan, of the Book of Job is characterized by his juridic argument. To attain the permission to "test" Job, to raise a claim against him, he arouses doubts in Job's honesty and simultaneously in God's justice whom he suspects to privilege the rich and fortunate man. The Satan is thus a "dissenter" who questions nothing less than the divine order. The two attitudes of his, the desire to question the divine order and the technique of using logical arguments, have been discovered already in Late Antiquity by the theologian and poet Ephrem of Nisibis (306-373) who does not hide his admiration of the Satan's appearance in court. He not only interprets the Satan's argument by furnishing it with a gnome-like principle, but even adds a scriptural verse that would have been fit to be used by the Satan:

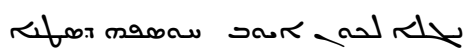

הד丶

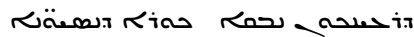

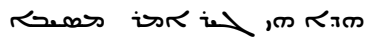

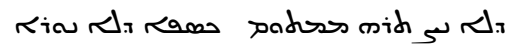

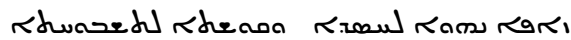

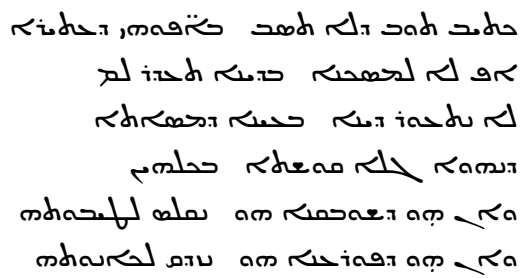

Let Job uncover for you

the impudence of Satan

how he asks and besieges

the Just One for permission

to test your minds

in the furnace of temptations.

This is what the abominable one said

"'no silver without fire

has ever been assayed';

Falsehood will be put to shame,

what is true will receive due praise".

It is written, furthermore (Lev 19,15):

"Show no favor to the rich,

Do not even help out a poor man in court;

Let not judgement be blinded

in the eyes of the scales

So that truth may be apparent in all things;

If it is a case of forgiveness,

let us praise his grace,

if of punishment,

let us acknowledge his justice" ${ }^{19}$

\subsubsection{Mt 4:1-11: Diabolos versus Jesus Christ}

To support one's argument with scriptural verses is a technique that in Ephrem's view relates Job's Satan to another prominent representative of the group of arguing demons, namely the demonic figure, Diabolos, who appears in the scene of Jesus' temptation. ${ }^{20}$

Both opponents act as if disputing in a court scenario. Both have equipped themselves with scriptural arguments. The scene, at the same time, is a psychological process in disguise. To juxtapose the contradicting options, it would not have needed a duo of dramatic characters; the process of deliberation should have taken place silently in Jesus' mind. However, it is the theatric staging of the antagonistic views that makes the practice of demonic testing/tempting clearly discernible. The authors of the Gospels are interested in profiling the dialectic process involved in Jesus' renunciation to accept the tempter's advice. Two contradicting options are calculated. It is up to the protagonist under test to decide about the desirable option ${ }^{21}$. It is noteworthy that Jesus distinguishes between his eloquent interlocutor-introduced as "Diabolos" and the spirit of evil that he senses to be looming behind Diabolos' approach, which he calls "Satanas", a reflex of the double image of the tempter that is etiologically explained in the Cave. 
1

2

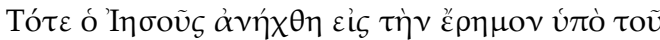

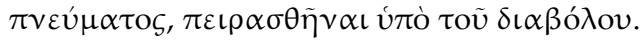

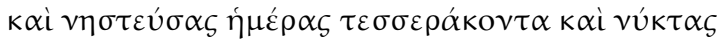

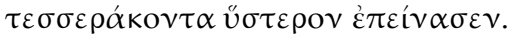

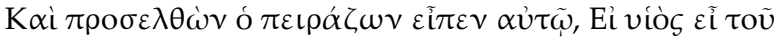

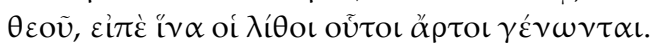

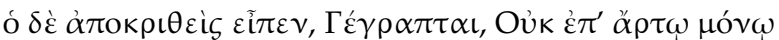

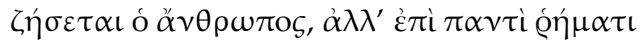

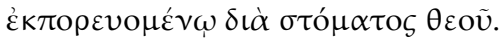

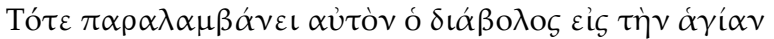

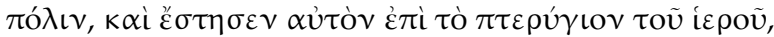

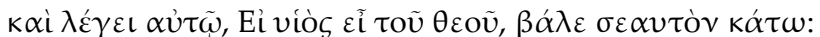

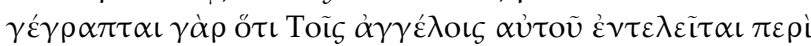

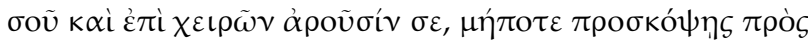

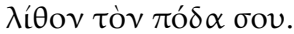

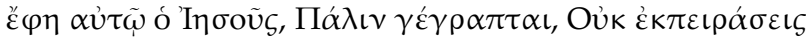

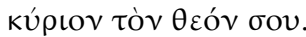

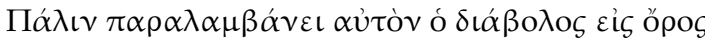

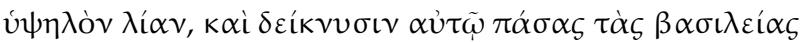

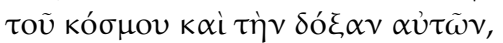

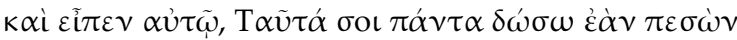

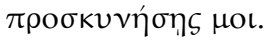

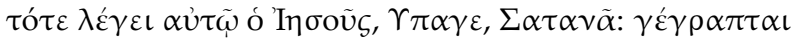

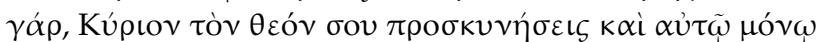
$\lambda \alpha \tau \rho \varepsilon \dot{\sigma \varepsilon \varepsilon \iota}$.

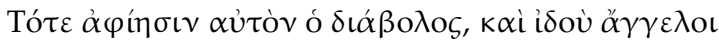

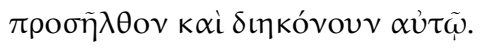

Then was Jesus led up of the Spirit into the wilderness to be tempted by Diabolos.

And when he had fasted forty days and forty nights, he was afterward hungred.

And when the tempter came to him, he said, If thou be the Son of God, command that these stones be made bread.

But he answered and said, It is written (Dtn 8:3), Man shall not live by bread alone, but by every word that proceedeth out of the mouth of God.

Then Diabolos taketh him up into the holy city, and setteth him on a pinnacle of the temple,

And saith unto him, If thou be the Son of God, cast thyself down: for it is written (Ps 91:11-12), He shall give his angels charge concerning thee: and in their hands they shall bear thee up, lest at any time thou dash thy foot against a stone.

Jesus said unto him, It is written again (Dtn 6:16), Thou shalt not tempt the Lord thy God.

Again, Diabolos taketh him up into an exceeding high mountain, and sheweth him all the kingdoms of the world, and the glory of them;

And saith unto him, All these things will I give thee, if thou wilt fall down and worship me.

Then saith Jesus unto him, Get thee hence, Satan: for it is written, Thou shalt worship the Lord thy God, and him only shalt thou serve.

Then Diabolos leaveth him, and, behold, angels came and ministered unto him.

2.4.4. Ephrem's De Paradiso XII:7 on Jesus' Opponent Diabolos: His Comment on the Ambiguity of Evil

Again, it is the technique of adducing scriptural verses that has intrigued Ephrem who comments on the scene:

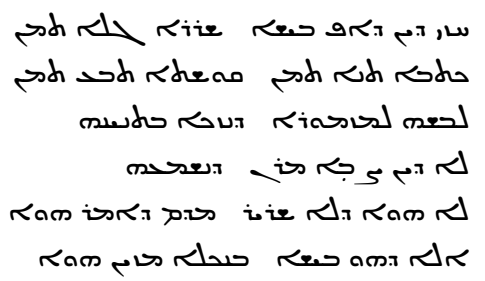

Observe how there too the evil one (bisha) revealed the truth:

He recited Scripture there He exacted truth there;

He clothed himself with a Psalm (90:11) Hoping to win by reciting it

But our Lord would not listen

To him-Not because it what he said was untrue but because the evil one had armed himself with deception ${ }^{22}$.

\section{The Qur'anic Iblīs Pericopes: The Origin of Evil Anchored in the Iblīs Narratives}

In the Qur'an, this "pre-history of creation" centered around Diabolos/Iblīs has been raised to the status of a major theologumenon. The protagonist, who already through his 
name $^{23}$, conveys the image of a post-biblical Hellenism imprinted identity. He re-appears in his Biblically familiar role as the dissenter, displaying the characteristics of a juridic agent: Voicing logical arguments, adducing scriptural - in this case Qur'anic-verses, but at times also arguing in a passionate tone. His aim is to question the divinely installed order. Although Diabolos'/Iblīs' story is known from fragments in earlier texts, nowhere in this literature has the story received the degree of attention it enjoys in the Qur'an. It is the Qur'an exclusively that has conferred on it a function in the history of the community. It is first told in sürat al-Hijr, Q 15, a Middle Meccan sura that for the first time draws a clear distinction between 'the newly constituted community', labelled al- $i b \bar{a} d$, and individuals not regarded to belong to them. ${ }^{24}$ It is here that Iblīs' seduction, 'ighw $\bar{a}{ }^{3 \prime}$ (Q 15:39: ughwiyannahum) is identified as the trigger of the unbelievers' erring and thus the cause of the sectarian divide in Mecca. Looking for a rationale for the telling of the Ibliss narrative, we will find it in the situation of the believers in Mecca. The newly defined ' $i b \bar{a} d$ are addressed as such in the immediately following narrative pericope ( $Q$ 15:43-48) featuring divine justice (Neuwirth 2017, pp. 244-67). The privileged social situation of the wrongdoers might inspire the feeling that moral shortcomings remain unrequited. Their enjoyment of privileges is, however, proof of their having fallen prey to lures of Ibliss/al-shaytān, meanwhile embodied in a multiplicity of tempting spirits active on earth. Their activity is however not completely evil, but willed by God who in Q 15:41 agrees to Iblis' proposal with the words "hādhà sirātun 'alayya mustaqim," "That is a straight path to Me'). It is also worth noting that Ephrem valorizes the activity of seduction as a challenging test.

Iblis does not act but argues. He refuses to venerate Adam out of the conviction that this would be improper. Spirits/angels/demons are created from more subtle material than men, fire, not clay. They are also aware of their privileged entrance into existence, which preceded that of the first man. An erstwhile accepted hierarchical order is thus being reversed. Consequently, his claim of a restitution is accepted: He is permitted to apply the same treatment that he suffered from to men on earth: To lure them into wronging themselves. The story of the eloquent figure of Iblīs, who acts in pre-existence, serves to distract the attention from the first man, Adam, who in the surrounding traditions stands in the limelight. The etiological task to explain the phenomenon of evil on earth is loaded on Iblīs and his alter ego, al-shaytān, who in the episode of the first couple's transgression (sūrat Tăhāa, Q 20) (Neuwirth 2017, pp. 354-57) appears for the first time. The scene is a kind of prologue to al-shaytān's powerful presence as the seducer of men on earth that had been conceded to his alter ego Iblīs after his act of disobedience. A similar entitlement of a demon and his hosts is highlighted in a Gospel exegesis by Ephrem, see below Section 3.2.

The story is retold six further times. The first three versions (in sürat al-Hijr, Q 15:2644 (Neuwirth 2017, pp. 240-44), sūrat Tạhā, Q 20:115-123 (Neuwirth 2017, pp. 349-51), sürat Sạd, Q 38:71-85 (Neuwirth 2017, pp. 545-8)) throw light on the emergence of the demonic realm that had been evoked in the briefly earlier sura, sürat al-rahmeñn, Q 55 (Neuwirth 2011, pp. 586-620). There, the two groups of beings, men and demons, were addressed together their differing material of creation, clay and fire, notwithstanding. Contrarily in late middle Meccan suras (sürat al-isrä, Q 17:61-65 (Neuwirth and Hartwig 2021, pp. 128-30), sürat al-kahf, Q 18:50-53 (Neuwirth and Hartwig 2021, pp. 807-8)) an enmity between the hosts/progeny of Ibliss, dhurriyyat Iblīs, and the progeny of Adam, banu Ādam,

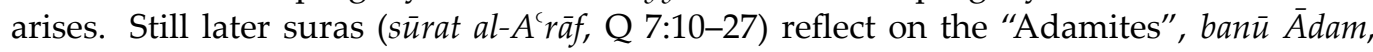
peculiar relation to Iblīs, or still later-in Medina (sürat al-baqara, Q 2:30-39)-completely revert the story to establish a new understanding of Adam, now viewed as the progenitor of men who-in spite of his proneness to commit transgressions - is finally elevated to the rank of a ruler over creation that-in the Qur'an's understanding - had been denied to him in the beginning. 
3.1. Q 15:26-44: The Sitz im Leben of the Iblīs Pericopes: Diabolos'/Iblīs' Dispatchment to Tempt Humans on Earth

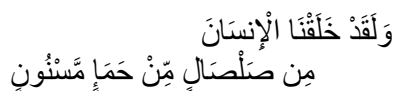

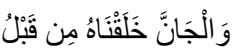

$$
\begin{aligned}
& \text { مِن نَّارِ السَّمُوِْ }
\end{aligned}
$$

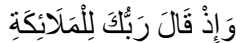

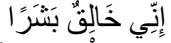

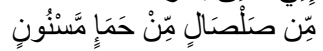

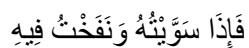$$
\text { من رُوجي }
$$

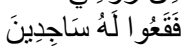

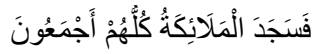

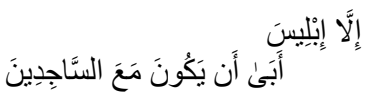

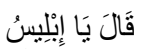

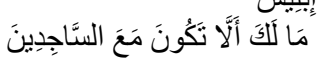

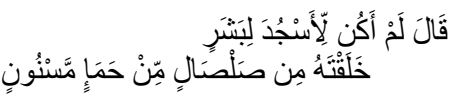

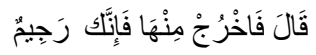

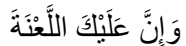

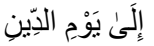

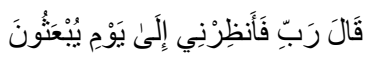

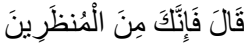

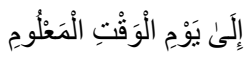

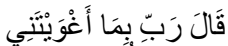

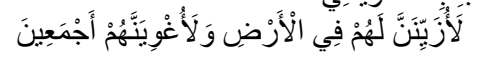

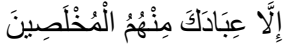

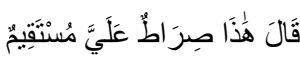

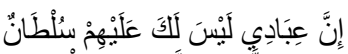

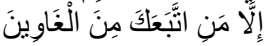

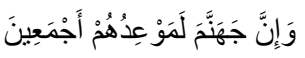
bow down before him,'

and the angels all did so.

But not Iblis:

he refused to bow down like the others.

God said, 'Iblis,

and he answered, 'I will not bow to a mortal

'Get out of here!' said God. 'You are an outcast, rejected until the Day of Judgement.' are raised from the dead.'

'You have respite,' said God,

'until the Day of the Appointed Time.'

all except Your devoted servants.'

\section{God said, 'That is a straight path to Me:}

you will have no power over My servants,

Hell is the promised place for all these
When I have fashioned him and breathed My spirit into him, why did you not bow down like the others?' You created from dried clay, formed from dark mud.'

Iblis said, 'My Lord, give me respite until the Day when they

Iblis then said to God, 'Because You have put me in the wrong, I will lure mankind on earth and put them in the wrong, only over the ones who go astray and follow you. $(\ldots)^{25}$

Iblīs, though refusing to heed a divine ruling, still holds a strong position: Quoting the divine announcement "I will create ... of dried clay, formed from dark mud" he interprets God's ordinance as an act of injustice against him who would have deserved the privileged status that the new creature is promised to receive. He therefore announces to exert vengeance in the very terms of his own suffering wrong. His logic proves persuasive: He is granted his demand to be installed as the tempter of humans on earth-a task that God explicitly agrees to.

\subsection{Q 38:71-85: Iblīs Turning Passionate-Quoting a Qur'anic Verse}

Sūrat Sạd, Q 38 focuses on antagonism and dissent ${ }^{26}$. In this context, Iblīs' erstwhile soberly pragmatic argumentation is blurred. His speech turns into a lament about his be- 
ing treated unjustly. In response to God's argument to have formed Adam with his own hands - though not "in his image and likeness" - Iblīs insists on being preferable to him in view of his nobler material of creation (fire instead of clay) a privilege that he "quotes" from Q 55:14-15: khalaqa l-insāna min sạlsāalin ka-l-fakhkhār lwa-khalaqa l-jānna min mārijin min $n \bar{a} r$, 'He created man from clay like the pottery, /the demons/jinn he created out of smokeless fire, where the diversity between the creation material of men und demons is explicitly mentioned, though not valorized. He repeats his intent to tempt humans even more emphatically - underscoring it by an oath - than he had presented it before. He however acknowledges the condition set in the earlier account: To leave the servants of God untouched. To fall prey to the lures of Iblis or to be spared his attacks becomes a criterion to distinguish between members of the community and others.

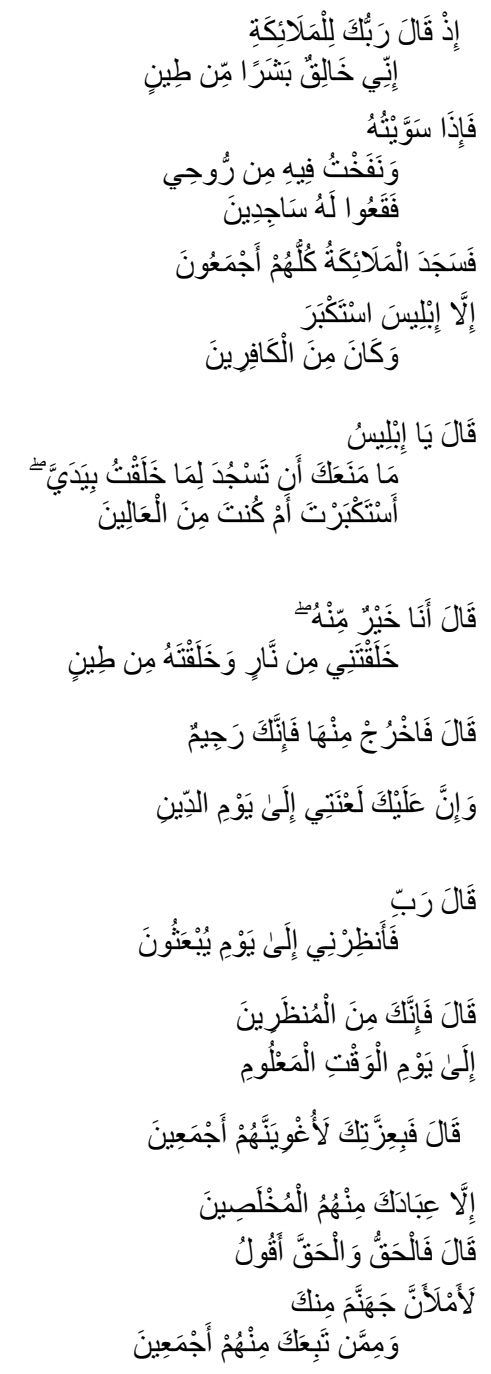

Your Lord said to the angels, 'I will create a man from clay.

When I have shaped him and breathed from My Spirit into him, bow down before him.'

The angels all bowed down together, but not Iblis, who was too proud. He became a rebel. God said, 'Iblis, what prevents you from bowing down to the man I have made with My own hands? Are you too high and mighty?'

Iblis said, 'I am better than him:

You made me from fire, and him from clay.'

'Get out of here! You are rejected: My rejection will follow you till the Day of Judgement!'

but Iblis said,

'My Lord, grant me respite until the Day when they are raised from the dead,'

so He said, 'You have respite

till the Appointed Day.'

\section{Iblis said, 'I swear by Your might!}

I will tempt all

\section{but Your true servants.'}

God said, 'This is the truth-I speak only the truth -

I will fill Hell with you

and all those that follow you.'

\subsection{Q 17:61-65: Diabolos/Iblīs Turns into Satan/Al-shaytān}

In late Middle Meccan texts, Iblīs turns even more aggressive, insisting on his nobler material of creation and even scorning at the newly created Adam, who is preferred over him. In this version, his stratagems are disclosed: It is his voice-Iblīs is a speaking figure, whose delusions are staged verbally - but he equally disposes of material lures like wealth and social status. Since the material lures are no more than adornments of earthly life, zinat al-hayāt al-dunyā, sūrat al-kahf, Q 18:46, ${ }^{27}$ all the promises made by Iblīs - who in this context is equaled with Satan-are "nothing but delusion". Iblīs' identification with Satan here resumes the earlier assignment form sürat TTăhā, Q 20, where Satan, al-shaytạn, appeared as the seducer of the first couple. The identification from $Q 20$ becomes standard: The event 


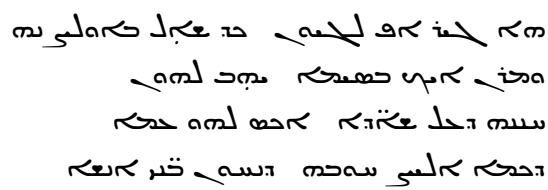

occurs after Iblīs' expulsion from the vicinity of God, the point from which on he becomes Satan, al-shaytān. As such, as the source of wrong attitudes (such as overspending) he had already figured in the decalogue of the same sura, sūrat al-Isrā', Q 17:27, wa-kāna l-shaytānu li-rabbihi kafūrā, where al-shaytạnn was qualified as "ungrateful" (see Neuwirth 2015).

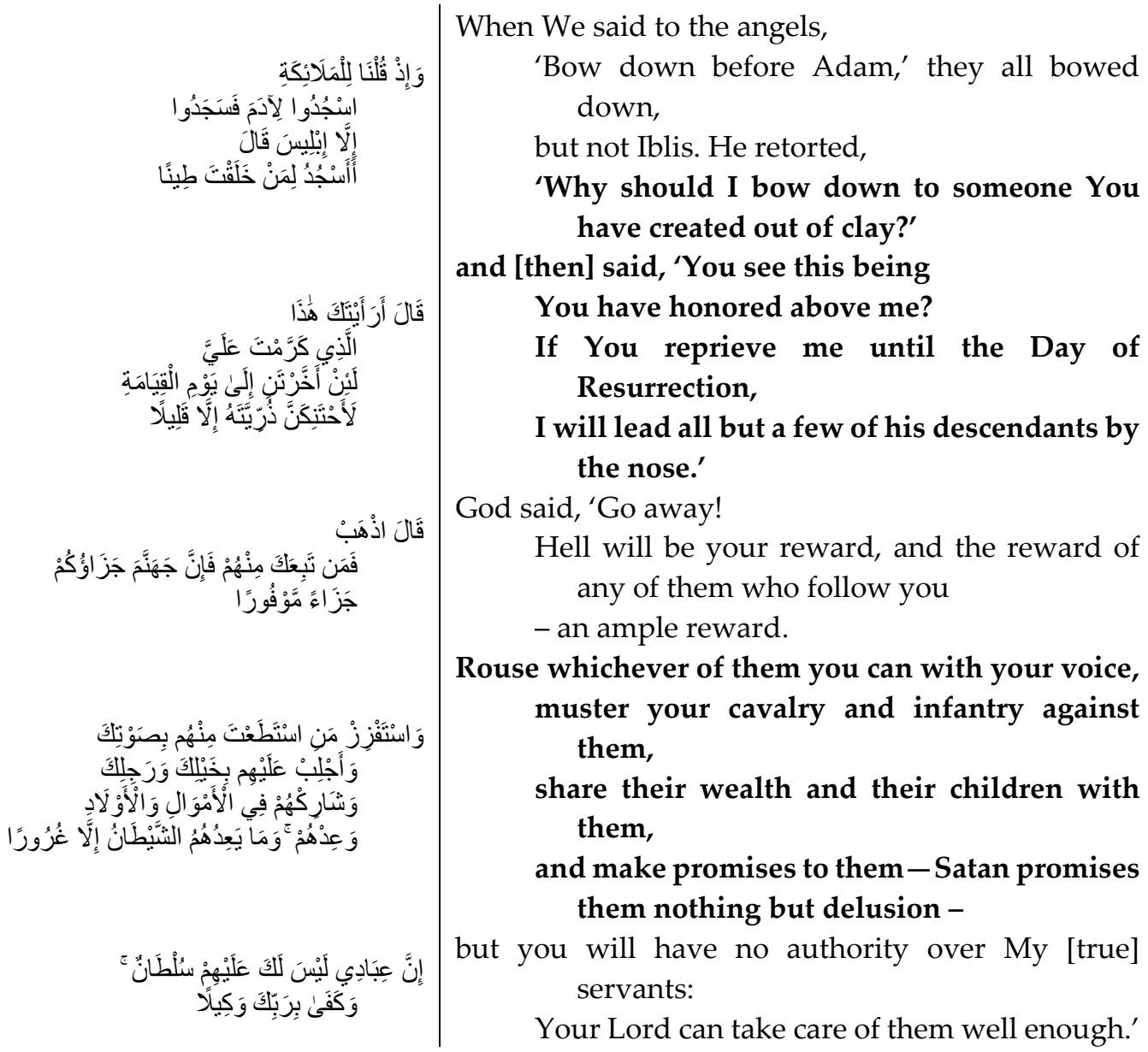

When We said to the angels,

'Bow down before Adam,' they all bowed down,

but not Iblis. He retorted,

'Why should I bow down to someone You have created out of clay?'

and [then] said, 'You see this being

You have honored above me?

If You reprieve me until the Day of Resurrection,

I will lead all but a few of his descendants by the nose.'

God said, 'Go away!

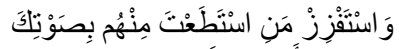

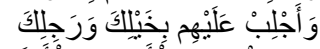

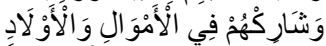

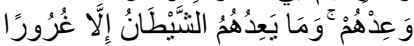

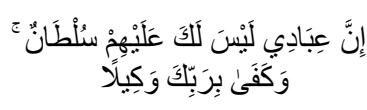

Hell will be your reward, and the reward of any of them who follow you

- an ample reward.

Rouse whichever of them you can with your voice, muster your cavalry and infantry against them,

share their wealth and their children with them,

and make promises to them - Satan promises them nothing but delusion -

but you will have no authority over My [true] servants:

Your Lord can take care of them well enough.'

\subsection{Ephrem's De Paradiso XII:8 ("Legion"): The Dispatchment of Diabolos' Hosts in His Gospel Exegesis}

Iblīs also resembles one of the major demons figuring in the Gospels, Legion, Mk 5:1-20, Lk 8:26-39. It is again Ephrem who has discovered the analogue and singled Legion out for his attainment of an authorized task in spite of his status of a demon.

Look at Legion ${ }^{28}$

when in anguish he begged, our Lord permitted and allowed him to enter into the herd (of swine); respite did he asked without deception in his anguish, and our Lord in his kindness granted this request. His compassion for demons is a rebuke to that people, Showing how much anguish his love suffers in desiring that men and women should live. ${ }^{29}$ 


\subsection{Q 18:50-53: Iblīs Disqualified as a 'Demon'}

At a still later stage-sūrat al-kahf, Q 18, is the last Middle Meccan sura-the shayātìn have moved into the focus. They are identified as Iblīs' progeny that have been accepted by some of the opponents as rivalling deities, spirits that accompany the unbelievers through their lives but desert them on the Day of Judgement. To dismantle their status as erstwhile angels, their creation time is put under scrutiny: It was not anterior to the creation of heaven and earth nor to members of their own species, and there is no basis for a claim to priority over others then. ${ }^{30}$

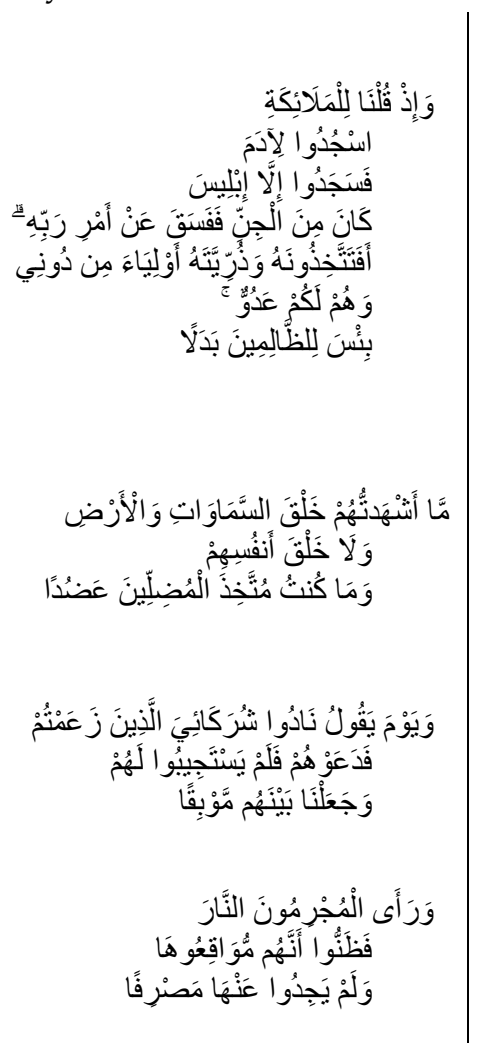

We said to the angels,

'Bow down before Adam,'

and they all bowed down, but not Iblis:

he was one of the demons and he disobeyed his Lord's command.

Are you [people] going to take him and his offspring as your masters instead of Me, even though they are your enemies?

What a bad bargain for the evildoers!

I did not make them witnesses to the creation of the heavens and earth, nor to their own creation;

I do not take as My supporters those who lead others astray.

On the Day God will say, 'Call on those you claimed were My partners,'

they will call them but they will not answer;

We shall set a deadly gulf between them.

The evildoers will see the Fire

and they will realize that they are about to fall into it:

they will find no escape from it.

It is noteworthy that at the same (late Middle Meccan) time, the shayātīn are at least partly rehabilitated. An entire short sura, surrat al-Jinn, Q 72, is dedicated to the case of a group of demons who are reported to have accepted the monotheistic faith on hearing a recitation of the Qur'an. Other suras, like sürat al-Mu'minūn, Q 23:97-98: wa-qul rabbi

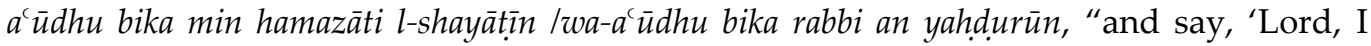
take refuge with You from the goadings of the evil ones; /I seek refuge with you, Lord, so that they may not come near me'", mention a prayer pleading to be spared the assaults of demons, and a particular formula to dispel them even acquires canonicity. $A^{\top} \bar{u} d h u b i-$ llähi mina l-shaytān al-rajīm (Neuwirth and Hartwig 2021, pp. 448-49). 'I take refuge to God from the cursed shaytān'. It epitomizes the Late Middle Meccan verses 114:4-6: min sharri l-waswāsil-khannās /alladhì yuwaswisu fì sudūril-nās /min l-jinnati wa-l-nās, "against the harm of the slinking whisperer-/who whispers into the hearts of people-/whether they be jinn/demons or people." By this time, the custom to confront demons with scriptural verses from memory, that could be derived from Jesus Christ's temptation event, had come to prevail in Christianity. Authors like the Desert Father Evagrios Pontikos (345-399) ${ }^{31}$ dwelt extensively on the technique (Clarke 1999). Iblīs, 'the arguer', at this stage has given way to a multitude of practitioners of his task, the shayātîn. It was their troubling presence that had, in the beginning, triggered the discussion on the origin of evil.

To counterbalance the power of the "progeny of Iblīs", the shayattinn, the rivalling deities (sürat al-Kahf, Q 18:50) in late Meccan time the "progeny of (the banū) Ādam", dhurriyyatuhum, are set into the limelight. They are portrayed in pre-existence being sworn into the keeping of strict monotheism: Indeed, sūrat al- $A^{c} r \bar{a} f, \mathrm{Q} 7$, the last Meccan sura 
to deal with Iblīs, entails a prediction-a vaticinatio ex eventu-about Adam's dhurriyya, which culminates in their acceptance of monotheism. Q 7:172: wa-idh akhadha rabbuka min ban̄̄ Ādama min zuhürihim dhurriyyatahum wa-ashhadahum 'alā anfusihim a-lastu bi-rabbikum qālù balā shahidnā an taqūlù yauma l-qiyāmati innā kunnā' an hāahhā ghäfilìn, "When your Lord took out the offspring from the loins of the Children of Adam and made them bear witness about themselves, He said, 'Am I not your Lord?' and they replied, 'Yes, we bear witness.' So you cannot say on the Day of Resurrection, 'We were not aware of this'". ${ }^{32}$

So, a threefold epistemic breakthrough has been achieved with the middle Meccan Iblis pericopes: They have offered an etiology for the dissent and rejection of truth on the side of the believers' opponents. More importantly, the stories have brought to light a new-epistemic - manifestation of evil and at the same time provided a practical device to confront it: The art of juridic reasoning including the quotation of Scriptural verses.

\section{The Qur'an's Embeddedness in Contemporary Discourses about the Origin of Evil:} Three Hermeneutically Distinguished Views

\section{Christian Aggrandizing of Adam's Mythical Dimension and Charging Him with 'Initial Sin'}

The Qur'anic shift of focus from Adam to Diabolos occurs in a milieu where the opposite perspective was powerfully prevailing: Adam's role among a majority of Christians had been aggrandized; his transgression had been conceptualized as the "original sin". "Adam" had entered the memory of the early Church as a double entendre; his name covers both the figure of primordial culprit, and at the same time the figure of his redeemer, Adam's fault is "blessed fault", felix culpa, that -in the words of a famous hymn - "earned for us so great, so glorious a redeemer". This massive spiritual enrichment of the figure claimed for the Christian tradition however provoked diverse responses crystallizing into distinct opposing positions - held not only in Judaism but occasionally in Eastern Christianity as well and which also have left traces in the Qur'an. These views will briefly be reviewed to put the Qur'anic Adam into relief.

\subsection{Paul and the Early Church}

It is no exaggeration to state that in Late Antiquity, the paradigm "Fall of man through Adam-Redemption of man through Christ" is powerfully present. Jesus Christ's selfsacrifice is necessitated by the state of the world, which is perceived deficient, "fallen", deprived of its primeval bliss. The predominant Christian tradition, which is based above all on the writings of St. Paul, presents Adam as an anti-type of Christ; he is the one who brought sin into the world; Christ is the one who took sin away from the world. Adam plucked sin from a tree; Christ nailed sin to a tree. Thus, in his letter to the Romans, Paul comments (5:12), "It was through one man that sin came into the world, and through sin death." He adds (v. 14) that this man "prefigured the one to come". In I Corinthians (15:22) Paul is still more explicit: "Just as all die in Adam, so in Christ all will be brought to life". 33 The fallen Adam, however, is inseparable from his typological counterpart: Christ arising from the dead, who is depicted to lend his hand to Adam, to drag him up from the underworld of Hades, the mansion of the dead. Numerous Byzantine icons also present the loosened fetters that have fallen from the hands of the redeemed who had been enslaved by their sins committed consequentially to Adam's sin. They have thus shaken off Adam's heritage that he had "bequeathed to them": Sin and mortality.

\subsection{The Concept of Inherited 'Initial Sin': Augustine's The City of God XIII}

The Church Father Augustinus even held that humans as the progeny of Adam are hereditary bearers of $\sin .^{34}$ 
Nam posteaquam praecepti facta transgressio est, confestim gratia deserente diuina de corporum suorum nuditate confusi sunt. unde etiam foliis ficulneis, quae forte a perturbatis prima conperta sunt, pudenda texerunt; quae prius eadem membra erant, sed pudenda non erant. senserunt ergo nouum motum inoboedientis carnis suae, tamquam reciprocam poenam inoboedientiae suae. iam quippe anima libertate in peruersum propria delectata et deo dedignata seruire pristino corporis seruitio destituebatur, et quia superiorem dominum suo arbitrio deseruerat, inferiorem famulum ad suum arbitrium non tenebat, nec omni modo habebat subditam carnem, sicut semper habere potuisset, si deo subdita ipsa mansisset. tunc ergo coepit caro concupiscere aduersus spiritum, cum qua controuersia nati sumus, trahentes originem mortis et in membris nostris uitiataque natura contentionem eius siue uictoriam de prima praeuaricatione gestantes.
For, as soon as our first parents had transgressed the commandment, divine grace forsook them, and they were confounded at their own wickedness; and therefore they took fig-leaves (which were possibly the first that came to hand in their troubled state of mind), and covered their shame; for though their members remained the same, they had shame now where they had none before. They experienced a new motion of their flesh, which had become disobedient to them, in strict retribution of their own disobedience to God. For the soul, reveling in its own liberty, and scorning to serve God, was itself deprived of the command it had formerly maintained over the body. And because it had willfully deserted its superior Lord, it no longer held its own inferior servant; neither could it hold the flesh subject, as it would always have been able to do had it remained itself subject to God. Then began the flesh to lust against the Spirit, Galatians $5: 17$, in which strife we are born, deriving from the first transgression a seed of death, and bearing in our members, and in our vitiated nature, the contest or even victory of the flesh. ${ }^{35}$

\section{Responses to Adam-Centered Views on the Origin of Evil}

There is no need to stress that this perspective on Adam is alien to the Qur'anic proclamation. Adam, who finds little mention in the Qur'an outside the Iblìs narratives, except in some_genealogical lists (sūrat $\bar{A} l{ }^{\prime} I m r a \bar{n}, Q$ 3:33, sūrat Maryam, Q 19:58, is remembered as a theologically relevant figure only in one single Medinan context: As an analogue to Jesus, the only biblical figure who-like Adam - did not come into being through physical procreation but was generated through the word: $Q$ 3:59: inna mathala ' $\bar{I} \bar{a} \bar{a}$ 'inda llāhi ka-mathali Ādama khalaqahu min turābin thumma qāla lahu kun fa-yakūn, "In God's eyes Jesus is like Adam: He created him from dust, said to him, 'Be', and he was". This is an obvious degradation of Jesus' dignity as the "second Adam". Adam's Qur'anic connection to Jesus strikingly bypasses the essential Christian theologumenon of the "two Adams": 1 Cor 15:47: "The first man is of the earth, earthy: the second man is the Lord from heaven".

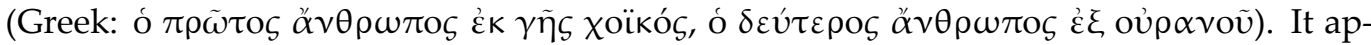
pears like a stratagem to downplay the theologically momentous relationship established between them in late Antique thinking, namely their complementary roles: One being the initiator of human enslavement by sin, the other the liberator from sin, the redeemer. ${ }^{36}$ This relation, not understood as an issue of mere causality, but embedded in a sophisticated anthropology, is found expressed in a number of Byzantine hymns celebrating Christ's passion and resurrection. ${ }^{37}$ Yet, in the Qur'anic discourse, the relation between the two is restricted to an almost formal, external resemblance, their being generated through the word, the mythically aggrandized Adam of the neighboring tradition is thus retreating into the background.

\subsection{Q 20:115-123: A Narrative Downplaying of Adam in the Qur'an}

There are, however, more explicit words about the mythic Adam's status in a narrative pericope, sūrat Tāhā Q 20:115-123. It offers a reverse narrative of the Biblical transgression story. Preluded by the already customary verse group about Diabolos' rebellion (verse 116) the story about Adam's transgression is strikingly de-dramatized. Adam, the protagonist of the story, is depicted as weak. His transgression is equaled to the forgetting of a covenant, ' $a$ hd, with God. He is also presented unaware of the momentousness of the divine directive that he risks transgressing. The sin of eating from the forbidden fruit in this story has no mythic implication, downplaying the theological dimension of the forbid- 
den fruit, there is only mention of the physical aspects: Since food is plenty in the garden there is no need to take care of the satisfaction of one's needs. A similar argument had been adduced by Chrysostom (344-407) in his exegesis to Genesis, ${ }^{38}$ where he reproaches the couple after the Fall of having satisfied their physical desires with the forbidden fruit in spite of the abundance of fruit in the garden: Their sin was declared "unnecessary". Thus, Adam's transgression is downplayed to little more than his illicit satisfaction of a physical need. The seducer-introduced as Iblis, the "dissenter in heaven" - at this stage of the development has fused with Satan, his malicious alter ego. Satan lures the couple into tasting the fruit, whispering promises of power and immortality. ${ }^{39}$ Instead, their eyes are opened, making them aware of their nakedness and the need to cover themselves. Adam in the story has no speech of his own but receives divine forgiveness and guidance. Though Adam is expelled from Paradise and warned of Satan as his enemy, there is no "Fall of Adam", whose fate on earth will depend on his obedience to the merciful God's rulings.

116

\section{6. 'Scientific' Approaches}

\subsection{A Psychological Response, Dispensing with Adam: Narsai's Yasra}

There are, however, different approaches to the existence of evil that dispense with the frame story of Adam's transgression. One prominent solution was the assumption 
of antagonist "inclinations", good and bad, innate in man. The juridic, courtroom-like exchange between the two persons, tempter and tempted, in the case of the Syrian theologian Narsai (d. 502) presents no reified dramatis figurae, instead, the inclinations themselves engage in a struggle. Their strife closely resembles the dialectical exchange between Diabolos and the soul of the tempted person, where right and wrong had been personified. In Narsai's presentation, again, a courtroom scenario is unfolded; the opponents are, however, the soul and (evil) thoughts, inclinations. The scene echoes the predominantly epistemeoriented struggle between the opponents in the Book of Job, the Gospels, and Ephrem's exegesis. Adam Becker illuminates the passage underlining the internal courtroom debate: "After this internal courtroom debate, in which the yatsra serves as a source of rebuke, Narsai quotes the extensive criticisms he received from his personified faculty of discernment (paroshutha), which commanded him to correct himself and rebuke the faults of his comrades" (Becker 2016, p. 185). The idea of an evil inclination (yasra) (Becker 2016) to be the source of transgression is in agreement with the rabbinic endeavors to review the problem of evil in terms of dynamics within the human soul-a way to respond to the Augustinian superelevation of the transgression of Adam.

The idea of the inclinations that in Narsai's theology is part of the Hellenist heritage that we have to presume as a given in the Mesopotamian milieu of the author.

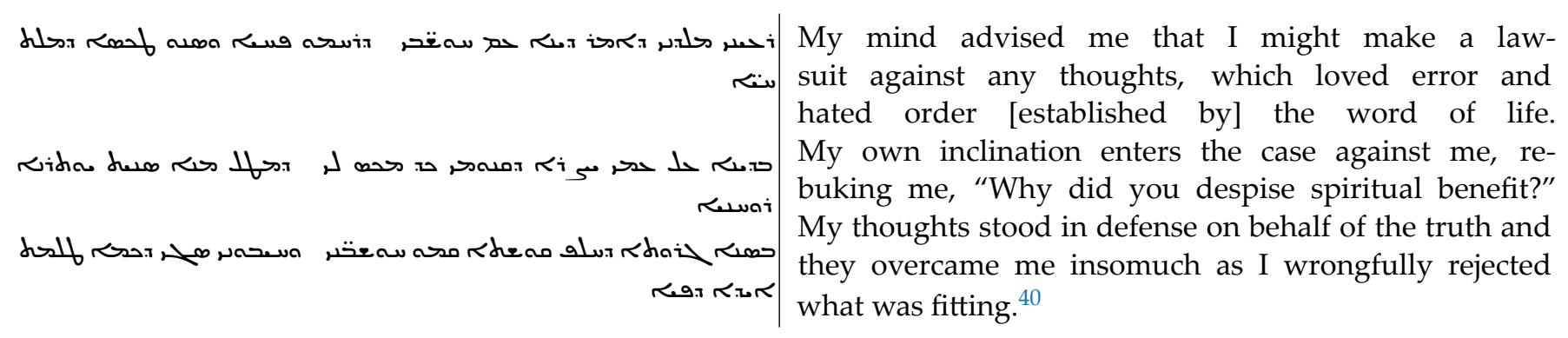

\subsection{Targum Jonathan on Gen 2:7: The Discovery of Two Inclinations}

Jewish tradition cherishes similar speculations about evil. They rely on the programmatic verse Gen 2:7 which has received a most sophisticated interpretation in its Aramaic rendering in Targum Jonathan that allows for the assumption of antagonistic inclinations. The text reads: and breathed into his nostrils the breath of life; and man became a living soul.

In Targum Jonathan, ${ }^{41}$ the Biblical verse is projected against its Late Antique background, where man is understood in a more sublime way: Provided not only with the breath of life, but also with an internal faculty, which enables him to differentiate between right and wrong due to his two innate inclinations.

Targum Jonathan, Gen 2:7

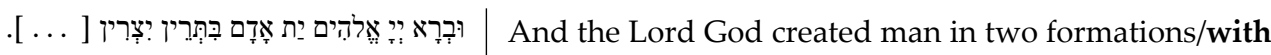

$$
\begin{aligned}
& \text { two inclinations [... ]. }
\end{aligned}
$$

It is this insight on which the rabbinic theory of the two inclinations will be based.

\section{3. bBerakhot 61a: A Rabbinic 'Philological' Exegesis of Gen 2:7 Producing the Concept of Yeser}

Similar to Narsai, the rabbis too were eager to downplay the role of Adam as the originator of 'original sin' in the Biblical Fall-narrative. They resorted to a 'graphical' argument: The orthographical phenomenon (of the doubling of the letter yod in wa-yyiser) was to serve as the point of departure for their speculation. The Talmud thus extends the 
insight of Targum Yonathan of the two inclinations into a sophisticated theory of human behavior, bBerakhot 61a:

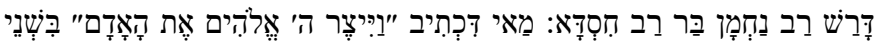

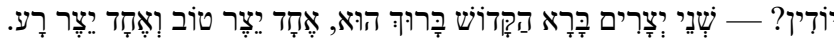

Rav Nahman bar Rav Hisda interpreted: What is the meaning of that which is written: "Then the Lord God formed [wa-yiser] man" (Gen 2:7), with a double yod? This double yod alludes to that fact that the Holy One, Blessed be He, created two inclinations; one a good inclination and one an evil inclination.

Resorting to a philological reading, the 'rabbis' interpreted the 'graphical' peculiarity of the writing wa-yyiser (with two yods) to point to a double phenomenon. Presupposing that there cannot be a meaningless element in the divine self-expression, they extracted meaning from the 'orthographical' peculiarity: They assigned to man/Adam two inclinations, an evil (yeser $h a-r a^{c}$ ) and a good inclination (yeser $\left.h a-t o v\right)$, while they considered the animals to be created without such a duality of character (in Gen 2:19, wa-yiser is written with one yod only). ${ }^{42}$ Through this operation, the rabbis not only explained the meaning of two orthographical forms of the word wa-yiser, but assigned the 'evil' to God's creation itself, downplaying the fall of Adam, and the first couple, rather locating the source of evil in the psychodynamics of the human self. ${ }^{43}$

According to the rabbinic understanding, each individual is in a constant state of struggle to control the evil inclination. Here, the Torah serves as a powerful weapon against the evil inclination-not unlike the stratagem to adduce scriptural verses in Evagrios Pontikos' Antirrhetikos. ${ }^{44}$ According to bQiddushin 30b, it is God himself who instructs the people of Israel to use Scripture as an antidote to hold at bay evil: "The Holy One, Blessed be He, said to Israel, 'My children, I created the evil inclination, and I created the Torah as its antidote. If you engage with Torah, you will not be given over to its power, as it is stated: 'If you do well, shall it not be lifted up?' (Gen 4:7) But if you do not engage in Torah, you are given over to its power, as it is stated: 'Sin crouches at the door'. (Gen 4:7)". 45

\subsection{Q 91:1-10: Qur'anic Echoes of the Concept of Inclination}

Some early Meccan sures seem to reflect the inclination theory though without relating it to the creation discourse, which at this time is still widely limited to physical aspects (see Sievers 2019). Particularly sürat al-shams, Q 91, testifies to the knowledge of two opposing inclinations in man - an antinomy that is considered as momentous as the cosmic antinomies 'day' and 'night', and 'sky' and 'earth' (see Neuwirth 2011, pp. 217-26).

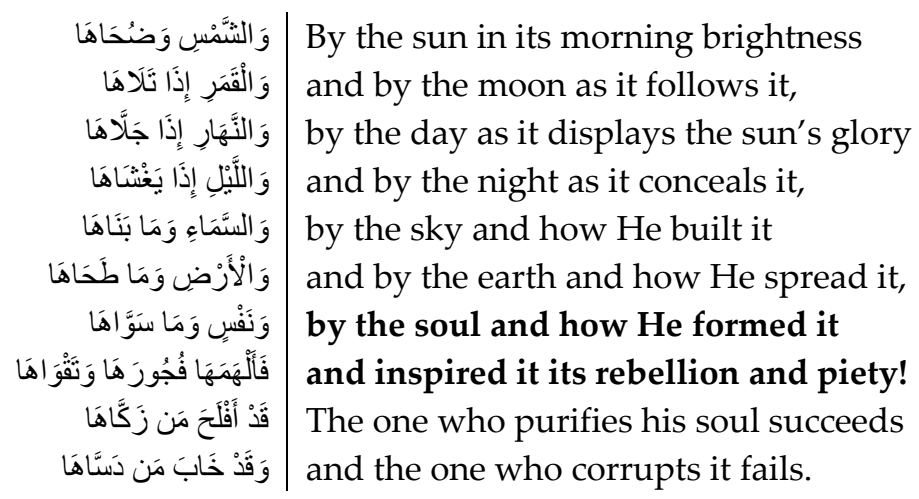

\section{From Myth and Speculation to History: The Rabbis Establish a Historical Event to Mark the Origin of Evil}

In reference to Dt 25:5-9, summarizing the history of the Jewish people David $\mathrm{H}$. Yerushalmi points a similar epistemic development, describing the turn from myth to history: "This is capsule history at its best. The essentials to be remembered are all here, in 
a ritualized formula. Compressed within it are what we might paraphrase as the patriarchal origins in Mesopotamia, the emergence of the Hebrew nation in the midst of history rather than in mythic pre-history, slavery in Egypt and liberation therefrom, the climactic acquisition of the Land of Israel, and throughout - the acknowledgement of God as lord of history" (Yerushalmi 1996, p. 12). In fact, in the rabbinic tradition, crucial events that were to turn into waymarks of theological speculation - often remembered through feasts - are located in the history of the Israelites to manifest the process of nation building: The exodus from Egypt, the wandering through the desert, the giving of the law, as the ultimate affirmation of the close relationship between God and his people. Even in the moment when Israel is about to receive the Torah, under the very wedding canopy when God gives the Torah-imagined as God's daughter-to Israel, they call for an idol, the Golden Calf, shaming their God and his acts of liberation from the yoke of Pharaoh. The rabbinic tradition compares Israel to an "insolent bride who is promiscuous already under her wedding canopy" ('aluvah kallah mezannah be-tokh huppatah) (bShabbat 88b). It is the sin of the Golden Calf that is understood as one of the most momentous events in the history.

\section{1. bSanhedrin 102a: The Idolatry of the Golden Calf as a Counter-Narrative to the Adam Myth}

Accordingly, the event at Mount Sinai is not only a manifestation of God's love but equally the benchmark for the emergence of evil. The rabbis resorted to the narrative of the Golden Calf (Ex 32) (Urbach 1975, pp. 554-64) to install a theologically charged narrative of origin to cope with the Christian grand narrative. It is the sin of the idolatry at Sinai, the construction of the Golden Calf, that would hold the Israelites responsible for any misfortune that would later befall the Jewish people. This insight has found "classical" expression in bSanedrin 102a:

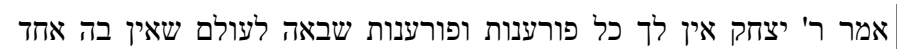

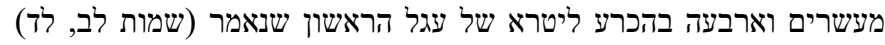
וביום פקדי ופקדתי עליהם חטאתם.
Rabbi Yitzhak says: You have no punishment that comes to the world in which there is not one twenty-fourth of the surplus of a litra of the first calf, as it is stated: "On the day when I punish, I will punish their sin upon them" (Exodus 32:34).

It is not the mythic Adam, then, who is accountable for the influx of sin into the world, but Israelites themselves, actively producing the calf and consciously indulging in idol worship. Sin is thus no longer a metahistorical category based in mythic beginnings, but located in the history of the Jewish people, bringing about all sorts of misfortunes - not only mortality. The sin of the calf was still understood as "being in the footsteps of Adam" (ExR 32:1); ${ }^{46}$ thus, the exegetes assigned to the idolatry at Sinai consequences similar to those resulting from Adam's transgression: The Israelites like Adam were accountable for their actions and passed on the consequences to generations to come. ${ }^{47}$

\section{2. bShabbat 89a: A Revision of the Biblical Story (Ex 32)}

Nevertheless, the rabbis were anxious to-at least partially-exonerate the Israelites and to attribute the idol-worship in the desert to the intervention of evil forces.

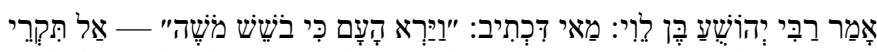

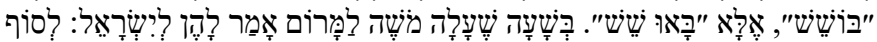

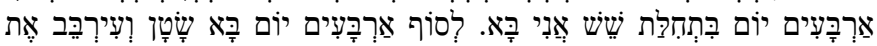

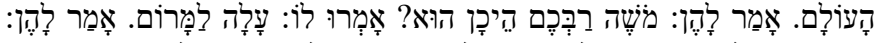

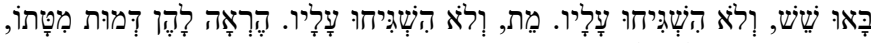

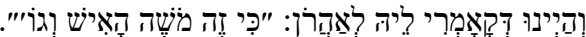

And Rabbi Yehoshua ben Levi said: [ ... ] When Moses ascended on High, [ ... ] Satan came and brought confusion to the world. He said to the Israelites: Where is your teacher Moses? [... ] He has not yet come. He has died. And they paid him no attention. Finally, he showed them an image of his death-bed. And that is what they said to Aaron: "This Moses, the man [who brought us up out of the land of Egypt, we know not what has become of him]" (Ex 32:1).

Not only can the interpretation be seen as a counter-narrative to the prevalent Christian version of the Fall, determining an individual point of departure for the emergence of 
evil, but equally, the exegetical reworking attests an earlier model: Not unlike Christian exegesis (Cave of Treasures), which downplayed the responsibility of Adam and promoted the role of the 'evil one', the rabbis introduced a satanic figure into the Biblical narrative. Again, it is not the sinful people that indulges in reprehensible idol worship of its own accord, but the initiative is taken by a satanic figure. Following his persuasive argument supported by a scriptural verse, he convinces them that Moses is dead and will not return, driving them to construct the Golden Calf and, ultimately, to commit idol worship.

\subsection{Q 20:83-99: Revised Version Resumed in the Qur'anic Golden Calf Story}

It is noteworthy that it is this revised reading of the story that has persisted in later tradition. In the Qur'an (sūrat Tạh $\bar{a}, \mathrm{Q}$ 20:83-98), the satanic figure is represented by al-Sāmirī ("the Samaritan"), an allusion to the Samaritan cult of calves installed by King Jerobeam (1 Kings 8:28-40). However, the Rabbis' rationale for highlighting the story, to extract the origin of evil from history, not from myth, does not transpire in the Qur'anic version, which recounts the episode as an event of the Israelites' past, rather abruptly following the mention of the exodus, vv. 77-82. Unlike the Biblical sequence, no mention of the mattan Torah, the touchstone of the Israelites' faithfulness to God, precedes.

[God said], 'Moses, what has made you come ahead of your people in such haste?' and he said, 'They are following in my footsteps. I rushed to You, Lord, to please You,'

but God said, 'We have tested your people in your absence: the Samiri has led them astray.'

Moses returned to his people, angry and aggrieved.

He said, 'My people, did your Lord not make you a gracious promise? Was my absence too long for you? Did you want anger to fall on you from your Lord and so broke your word to me?'

They said, 'We did not break our word to you deliberately.

We were burdened with the weight of people's jewellery, so we threw it [into the fire], and the Samiri did the same,'

$[\ldots]$ قَالَ فَمَا خَطْبُكَدَ يَا سَامِرِيُّ

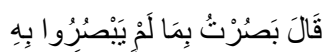

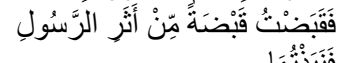

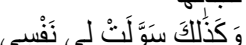

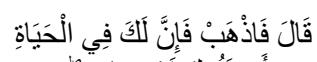

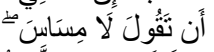

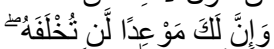

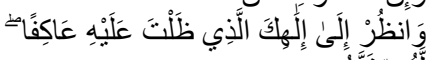

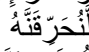

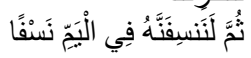

Moses said, 'And what was the matter with you, Samiri?'

He replied, 'I saw something they did not;

I took in some of the teachings of the Messenger but tossed them aside:

my soul prompted me to do what I did.'

Moses said, 'Get away from here! Your lot in this life is

to say, "Do not touch me,"

but you have an appointment from which there is no escape.

Look at your god which you have kept on worshipping -

we shall grind it down and scatter it into the sea. 
Though all three hermeneutically distinguishable approaches to the origin of evil, the narrative, the 'scientific', and the historical, are reflected in the Qur'an, they have attracted different implications. The mythic aggrandization of Adam is critically reviewed and rejected as it was also in Jewish tradition. The 'scientific approach', the speculation about the two inclinations, is shared by the Qur'anic community though it has remained low profile. The historization of the origin of evil however, which rabbinic Judaism highlights, the event of the Golden Calf, is only faintly reflected in the Qur'an, reduced to its mere plot. Seen against the backdrop of the diversity of the etiological explanations of evil, the Qur'anic choice of a complete reversal of the Biblical derivation appears as only one of a plurality of options.

III. Diabolos'/Iblīs' Critical Insight into the Ambiguity of Man Reclaimed by God Himself: A New Perspective on Sin/Evil

\section{Q 2:30-39: Adam Redressed as the Representative of Humankind}

The Meccan understanding of evil as a primarily epistemic issue, which did not confront the problem of moral evil, in Medina is revisited. In the last reference to Iblīs in sürat al-Baqara, Q 2, moral evil as part of the mundane political order enters the scene. Adam's installment as a khaliffa on earth, will cause moral evil to happen, transgressions such as had been discussed in the Qur'anic decalogues (Neuwirth 2015). However, it will be tolerable in view of Adam's newly acquired knowledge about all creation and his being spoken to by God.

It is noteworthy that moral evil, contrary to the Christian notion, is accommodated without recourse to a mythic etiology. In Medina, where earlier pericopes are re-read under a new political perspective, with the community as a capable political player, the dilemma of how to deal with moral evil can be approached optimistically. Adam, now representing humankind - once weak and forgetful-has grown into a figure who can be charged with a major political function, to take upon himself the task a ruler on earth.

The pericope in sürat al-Baqara, Q 2, entails a number of allusions to more universal Biblical and post-Biblical discourses, which need to be remembered to elucidate some political sub-intentions. The angels warn God to install a khalifa anticipating his causing of bloodshed, an allusion to Gen 9:6 ${ }^{48}$ that proves them conscious of the momentousness of the sin that will come into the world with Adam. 
30

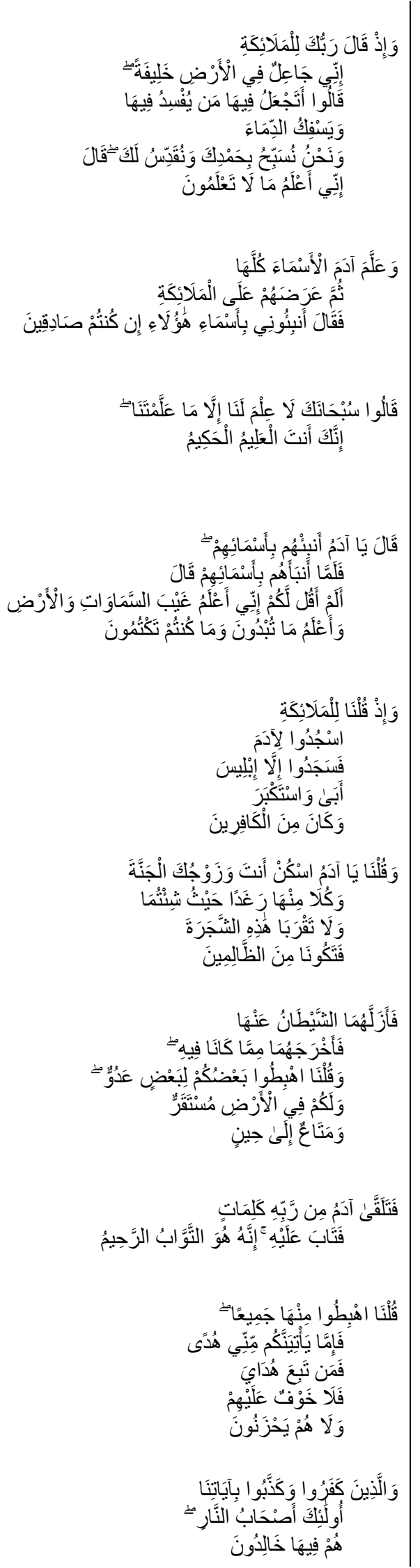

When your Lord told the angels, 'I am putting a viceroy on earth,' they said, 'How can You put someone there who will cause damage and bloodshed, when we celebrate Your praise and proclaim Your holiness?', but He said, 'I know things you do not.'

He taught Adam all the names [of living beings], then He showed them to the angels and said, 'Tell me the names of these if you truly [think you can].'

They said, 'May You be glorified! We have knowledge only of what You have taught us.

You are the All Knowing and All Wise.'

Then He said, 'Adam, tell them the names of these.'

When he told them their names, God said,

'Did I not tell you that I know what is hidden in the heavens and the earth,

and that I know what you reveal and what you conceal?'

When We told the angels,

'Bow down before Adam,'

they all bowed. But not Iblis,

who refused and was arrogant:

he was one of the disobedient.

We said, 'Adam, live with your wife in this garden.

Both of you eat freely there as you will,

but do not go near this tree,

or you will both become wrongdoers.'

But Satan made them slip, and removed them from the state they were in.

We said, 'Get out, all of you! You are each other's enemy.

On earth you will have a place to stay and livelihood for a time.'

Then Adam received words from his Lord and He turned back to him. He is the Ever Relenting, the Most Merciful.

We said, 'Get out, all of you!

But when guidance comes from $\mathrm{Me}$, as it certainly will,

there will be no fear

for those who follow My guidance

nor will they grieve -

those who disbelieve and deny Our messages

shall be the inhabitants of the Fire, and there they will remain.' 


\section{Anti-Messianic Dimensions of the Pericope}

God's designation of the ruler to be established, khalifa, entails a further Biblical allusion. Philological attempts to explain the title, which literally means "successor", are numerous (al-Qādī 1988; Steppat 1989). They have, however, ignored the ideological undertone inherent in the title: The Davidic dignity that is evoked here. Khalifa, which was already introduced as a title in sūrat Sạd, Q 38, renders the Biblical 'eternal, God pleasing king' embodied in David and his house. In Q 38, a report about the Biblical David had been extended by a messianism critical remark (Neuwirth 2017, pp. 544-53, in particular, pp. 551-52):

\begin{tabular}{|c|c|}
\hline 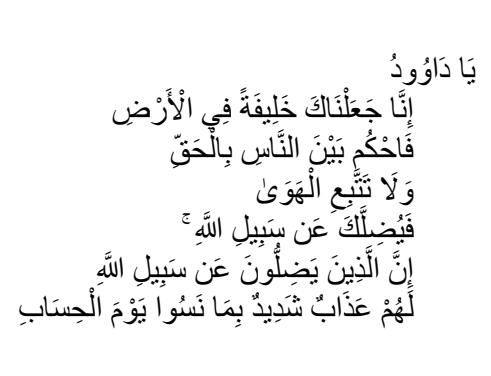 & $\begin{array}{l}\text { 'David, } \\
\text { We have assigned you a viceroy on earth. } \\
\text { Judge fairly between people. } \\
\text { Do not follow your desires, } \\
\text { lest they divert you from God's path: } \\
\text { those who wander from His path will have a } \\
\text { painful torment because they ignore the Day } \\
\text { of Reckoning.' }\end{array}$ \\
\hline
\end{tabular}

The title khalifa was applied to David, targeting not however the figure of the Biblical narrative presented in the preceding verses, but the imagination of a Messianic ruler that had arisen in Late Antiquity ${ }^{49}$-Messianic thinking seems to be criticized here. The ideal ruler, khalifa, the Davidic messiah, expected in the Jewish milieu, should not be overbearing. His prerogatives are curtailed in view of his eschatological accountability.

The extraordinary dignity assigned to David in Q 38 as a given, without further explanation, matches the uniquely privileged rank he (and his house) is granted in the Biblical context. Although no verbal translation can be claimed, the assignment should be understood as a reference to 2 Sam 7:16:

Thine house and thy kingdom shall be established for ever before thee: thy throne shall be established forever.

The title of the "everlasting king" that had been promised to David's house in the Bible could be properly rendered by khalifa in view of his uniquely close relation as a God (Biblically: A God-pleasing king, in the Qur'an: /a viceroy of God) ${ }^{50}$.

The status of David was claimed by the current messianic movements for the utopian David still to come. Even this figure would, however-according to sūrat $S \bar{a} d, \mathrm{Q} 38$ - not reign souverain but would be subject to the rules set for the eschatological judgment. The short address to David should be read as an attempt to restrict messianic hopes of the time, (Neuwirth 2020). Applied to Adam in sürat al-Baqara, Q 2, the dignity of a khaliffa is reconsidered a second time and essentially revised. Being detached from the David relation, the reference is charged with new meaning. Instead of the utopian David-be he the paragon of Jewish speculations or be he the Biblically coded Christian messiah-a substantially different - non-mythical but physically real-bearer of the title is focused -a silent rejection of messianism.

\section{The Gist of the Pericope: The Unconditioned Divine Commitment to Man}

Adam, i.e., mankind, having been granted divine knowledge, has become superior to the angels. Although the workings of the Shaytạn, Iblīs' alter ego, had made him slip, he isthanks to God's turning to him-entitled to re-enter into God's grace. Iblīs is not blotted out, but simply removed into the background, remembered as the primordial disobedient, whose works however remain part of the divine game of testing humans. His assaults thus remain the trigger of the malaise in the world-which is part of God's stratagem to educate the humans, to lead them to maturity. 
The theologically most important point of this pericope is however the assurance of enduring divine acceptance of man. Words of God-empathic, though not benevolent-in the Meccan suras had been addressed to Iblīs in recognition of his insight into the ambiguity of a 'second power in heaven'. In Medina, where an optimist attitude towards men has become prevailing, divine words, indeed an unconditioned benevolent divine address, are directed to Adam.

This divine magnanimousness is not a new theologumenon. In bSanhedrin $\mathbf{3 8 b}$, human deficits are faded out in view of God's everlasting faithfulness to humans. The Qur'anic angels of $Q$ 2:34-now a group less prone to follow directives blindly - resemble those from rabbinic tradition who even risk their lives when opposing a divine plan:

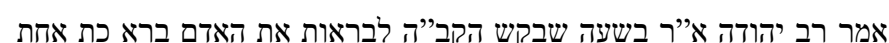

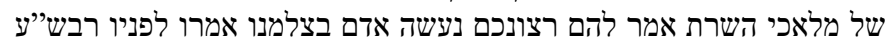

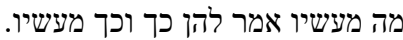

אמרו לפניו רבש"ע (תהלים ח, ה) מה אנוש כי תזכרנו ובן אדם כי תפקדנו

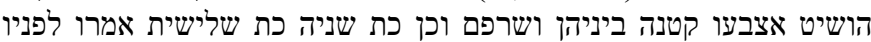

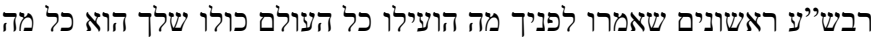
שאתה רוצה לעשות בעולמך עשה.

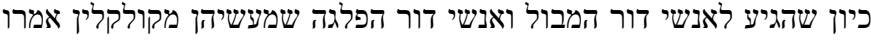

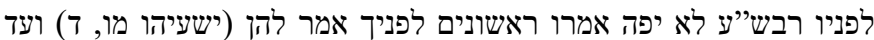
זקנה אני הוא ועד שיבה אני אסבול וגו'.
Rav Yehuda says that Rav says: At the time that the Holy One, Blessed be He, sought to create man/Adam, He created one group of ministering angels. He said to them: If you agree, let us fashion a man in our image. They said before him: Master of the Universe, what are the actions of this one You suggest to create? God said to them: His actions are such and such ... They said before him: Master of the Universe: "What is man that You are mindful of him? And the son of man that You think of him?" (Ps 8:5). God outstretched His small finger among them and burned them. And the same with a second group. The third group that He asked said before Him: Master of the Universe, the first two groups who spoke their mind before You, what did they accomplish? The entire world is Yours; whatever You wish to do in Your world, do.

When arrived the time of the people of the generation of the flood and the people of the generation of the dispersion, whose actions were ruinous, they said before God: Master of the Universe, didn't the first speak appropriately before You? God said to them: "Even to your old age I am the same; and even to hoar hairs will I suffer you" (Is 46:4).

The angels are knowledgeable of man's deficiency, displayed in history paradigmatically twice: Before the flood and during the erection of the Tower of Babel. They thus do not need to name further historical proofs for their pessimist apprehension of Adam's elevation. Yet the divine response-God is conscious of the deficits of man but in spite of that clings faithfully to him - remains the decisive verdict.

It is this verdict that is equally hidden in the Qur'anic pericope where the angels' warning of Adam are not proven wrong but yet outvoted. Adam has received "words" (Q 2:37) that secure his status as a God-pleasing political agent.

"With the divine sending down of Adam as ruler to the world, human political power is legitimized. An understanding of the important verse $Q$ 2:30 proved so suggestive that the dynasty of the Umayyad Marwanids deemed it appropriate to introduce the figure of Adam into their iconography of rulership (Fowden and Fowden 2004, p. 159). Adam is depicted in the throne hall of the Umayyad residence at Qusayr 'Amra as the "type of the ruler" whose image is placed above the throne of the caliph. In the context of the proclamation, the pericope $Q$ 2:30-38 appears to be an expression of the perception of a salvation historical turn. It shows that the primordial project of "God's representative on earth" sent down into the world with Adam, has in the current moment, in view of the newly constituted community who is now capable of representing the divine will, entered into a phase in which it can be politically realized in a way pleasing to God" (Neuwirth 2010, p. 611 [English: pp. 377-78]). 


\section{Conclusions}

What is the contribution that critical scholarship can offer to Qur'anic studies? There are three aspects that this article wishes to pursue: First, the questioning of the hegemony of the prevailing approach of reception history. For almost 200 years, western scholars (Geiger 1833; Speyer 1931) have felt urged to complement, more precisely to rectify, "traditional" readings of the Qur'an, demanding a new contextualization of the Text. They excised the Qur'an from its Ancient Arab framework documented in the sira and in Islamic exegesis. Pre-qur'anic monotheist traditions moved into the foreground, established as the new parameters for a historically adequate understanding of the Qur'an.

Since critical scholarship was initiated by the reform movement of "Wissenschaft des Judentums ${ }^{51}$. Rabbinic traditions stood in the focus first, Christian theologumena followed suit (Andrae 1926), more recently ${ }^{52}$, Syriac ecclesiastical writings. These are considered to provide the backdrop of the Qur'an. Some scholars regard them as the sources for particular ideological trends apparent in the Qur'an ${ }^{53}$, others - contrarily - consider them as triggers of a particular approach in Qur'anic polemics, i.e., the "contrafactual" (Ghaffar 2020). Reception history, though immensely relevant, risks to prioritize earlier traditions over the later. To avoid such an imbalance, which blinds us to the genuinely innovative contribution of the Qur'an to the epistemic space of Late Antiquity, we need to widen our horizons to encompass the "great questions" of the time, which might have had a bearing on burning issues discussed in the text, i.e., they may throw light on the "Sitz im Leben" of individual pericopes. With this inquiry, the paper surpasses the narrow perspective of the Qur'an's textuality and pays tribute to its processual character as a proclamation that demands diachronic treatment.

The second tenet is to sketch the Qur'anic embeddedness in contemporary discourses about the origin of evil. From among the numerous "burning" and fiercely debated questions, this paper has focused the phenomenon of "evil" that was realized to have been instrumental in in the Middle Meccan sectarian quarrels of the community. Retracing it to its primordial "origins", the community came across the figure of Diabolos/Iblīs whose first articulation of dissent, the refusal of a divine ruling, was seen to have engendered the phenomenon of human erring from the right path. The community thus subscribes to the "alternative creation story" reported in various apocrypha that has not Adam, but the angels created first and which charges one of these, Diabolos, with the first and fatal transgression. He moves into the foreground and for a long period of time overshadows the Biblical protoplast who, however, looms in the background being the cause for the existence of evil in the neighboring Christion tradition.

What is remarkable here is that the canonical Biblical etiology of evil-the transgression of Adam - was not simply replaced by another but was debated on a hermeneutical level: It triggered the discovery of the ambiguity of evil as a dialectical phenomenon. This perception of the initiator of evil, Ibliss, the "Arabic Diabolos", has earned him the honorary title of the inventor of qiy $\bar{a}{ }^{54}$, of 'juridic reasoning' - a permeability of the concept of evil that has elsewhere not been achieved.

To locate the Qur'anic Iblīs pericopes in their epistemic space (cf. Schmid et al. 2016), the figure of Diabolos was reconnected to his Biblical genealogy (Book of Job, Gospels) - a step that fully brought to light his most characteristic trait: His rhetorical skills. This did not remain unnoticed by Late Antique exegetes (Ephrem, Narsai), who fully appreciated his stratagems of arguing in spite of his inacceptable intent of seducing the humans. They moreover constructed a proper framework for his acts: A courtroom scenario where right is negotiated against wrong so that Diabolos' dealings appear as a kind of probing humans rather than straightforward seduction.

The third tenet is to profile the Qur'an's particular innovative dealing with the given pessimist prospects concerning man's behavior on earth. For this purpose, the article pursues the development of Diabolos' relation to Adam, who through Christian theology had become paramount, even inseparably connected to his messianic namesake, the "second Adam", charged with the undoing of Adam's failure and thus the redemption of mankind. 
How did Judaism, how did the Qur'an cope with this solution of the Adam question? To downplay Adam's capabilities ( $Q$ 20) was not the only way; speculations about an innate inclination towards evil (rabbinic Judaism, Q 90) was another. The final rehabilitation of Adam/mankind could, however, not be achieved by the circumvention of the Christian dogma, it needed to be grounded in a new image of man. Both the Jewish vote for a Davidic restorer of human integrity (rabbinic Judaism, Q 38) and the Christian vote for an eschatological redeemer needed to be dealt with: The Qur'anic proclamation expresses the strong confidence in man's ability to practice good governance on earth, independent from options of soteriological support that is achieved in the end of the Qur'anic development ( $Q$ 2), the primordial Adam is finally allowed to play the role he was destined for: To be the viceroy of God on earth.

Author Contributions: Both authors contributed equally to the paper. Both authors have read and agreed to the published version of the manuscript.

Funding: This research received no external funding.

Conflicts of Interest: The authors declare no conflict of interest.

\section{Notes}

1 Thought-provoking proposals to rethink the figure of Satan range from such Nahda authors as al-Zahāwī (1931) (cf. van Leeuwen 2015) to the works of al-Azm (1969, pp. 99-132) and al-Azm (1991). They have, however, found little attention in the Western discussion.

2 In chronological sequence: Q 15:26-48, Q 20:115-127, Q 38:71-85, Q 17:61-65, Q 18:50-53, Q 7:10-30, Q 2:30-39.

3 These of course are deemed momentous as well, see on the Qur'anic Decalogue and various 'catalogues of vices', see Neuwirth (2015).

4 The only post-biblical text referenced in the following continuously, the Life of Adam and Eve, will not be used as an 'intermediate tradition' let alone a 'source", to allow us to make a statement about the origin of a particular Qur'anic section from a distinct theology, but rather introduced as a para-Biblical text providing basic knowledge not recorded in the Bible. The numerous further Late Antique texts (rabbinic, ecclesiastical) are adduced to throw light on the diversity of approaches to the problem of Diabolos' ambiguous nature (Book of Job, Ephrem) and on the alternative attempts to explain the origin of evil (St Augustine, Rabbis).

5 This approach, introduced by Nöldeke (Nöldeke 1860, Nöldeke and Schwally 1909) is still fervently debated, see Stefanides (2008).

6 (Neuwirth 2017). A comparable case of the birth of an ideology: The emergence of a Satan concept, from a sectarian crisis, has been discussed by Pagels (1995).

7 For demons in Late Antiquity see Clarke (1999).

8 (Neuwirth and Hartwig 2021, pp. 30-40; Ghaffar 2020).

9 (Neuwirth 2010, pp. 305-8 [English: pp. 182-85]). See the commentary on early suras (Q 86:5; Q 80:24; Q 75:27; Q 78:6; Q 88:17; Q 77:25) entailing verdicts again al-insān (Neuwirth 2011, pp. 324, 385, 424-25, 457-59, 479, 509).

10 The Life has survived in Latin and-in a slightly different form under a different title-in Greek as well. For a reconstruction of its original Greek text see Knittel (2002). The complex transmission history has been tackled by Pagels (1991). See for more details (Reynolds 2006).

11 Its provenance, Jewish or Christian, had long been disputed, most recent studies opt for a Jewish text, see the discussion in (Minov 2015).

12 (Toepel 2013). An earlier dating is advocated by Reynolds (2006, p. 71).

13 The plural form 'Let us make man' (na'aseh Adam) has attracted several interpretations. According to GenR 8:3-4: God took council with the angels, who were also created beings (Gen 2:1; Ps 104:2-5). Cf. (Kugel 1997, p. 62).

14 The triple designation used here is meant to encompass the diverse perceptions of the figure. Diabolos, in the Hebrew Bible (Book of Job, Sacharia, Chronicles), he is a member of the divine court; he is called "the Satan" (Book of Job, Sacharia, Chronicles), still mostly considered as a morally neutral figure, see Seminar materials kindly provided by Klaus Bieberstein (2020, unpublished materials). In the New Testament-under the name of Diabolos, the most frequent rendering of satan in the Septuagint-he occasionally continues to serve as a juridic accuser, but simultaneously appears under the Hebrew name of satan to represent the "evil one". In the Qur'an the figure-named Iblīs-appears in the juridic role, he is re-named al-shaytān only after his expulsion from the vicinity of God. On the etymology of the expression Iblīs and shaytān (cf. Horovitz 1926, p. 87, resp. pp. 120f.).

15 Text and Translation: Charles (1913).

16 Translation: Toepel (2013, pp. 541-42). Syriac original is quoted after (Ri 1987, pp. 13-25). 
18 Gen 2:7: "And the Lord God formed man of the dust of the ground, and breathed into his nostrils the breath of life; and man became a living soul." (The final verse of Is 2 is missing in the Septuagint.)

19 Saint Ephrem (1990, pp. 164-65).

20 See the parallel in Lk 4:1-13 and the summary in Mk 1:2-13.

21 Elaine Pagels, who is less interested in the rhetorical devices employed by the antagonists than in the ideological background, comments: "Here (satan is) turned into a caricature of a scribe a debater skilled in verbal challenge and adept in quoting the scriptures for diabolic purposes, who repeatedly questions Jesus' divine authority ... "; cf. (Pagels 1995, p. 81). (Saint Ephrem 1990, p. 164, translation by Sebastian Brock).

Iblīs is derived from Diabolos, see Horovitz (1926, p. 87).

24 We do not subscribe to Fred Donner's broad concept of the community (Donner 2010), but rather share the reservations noted by Khorchide and Stosch (2019, p. 42 note 2). The Meccan community should not be assumed as pre-existing, it emerges through the proclamation of the Qur'an.

25 Translation of the Qur'anic texts: Muhammad Abdel Abdel Haleem (2010), The Qur'an. English Translation with Parallel Arabic Text (slightly modified).

26 (Neuwirth 2017, pp. 545-48). The sura chronologically is preceded by Q 20, which however is discussed under a more discursive aspect below, see II Section 5.1 .

The pericope that would chronologically belong after Q 38 and Q 17 will be discussed in Neuwirth and Hartwig (2021).

Mt 8:28-34, Mk 5:1-20, Lk 8:26-39.

(Saint Ephrem 1990, p. 163).

Their creation as prior to that of man/Adam is a standard argument of the demon to defend his claim to a privileged rank. Zellentin (2017, pp. 54-125), has claimed the chronological argument in the Qur'an to be a reference to the Cave. There is however an extensive rabbinic discussion (GenR 1:3), which illuminates the entire discourse, see the commentary on Q $18: 51$ in (Neuwirth and Hartwig 2021, pp. 807-8). Equally current is the argument of the nobler material see Awn (1983, pp. 34-35): ““I am better than he! Me You created from fire; him You created from clay"' (Qur ān 7:12). Iblīs' pride and arrogance spring from his belief in the superiority of his created essence over that of Adam. Fire seems both more noble and more powerful than the clay of man; in fact, fire can obliterate clay entirely in the scorching heat of its flames. There is no doubt in Iblīs' mind that he, the superior being (fädil), should, therefore, never bow before this weakling who has, for the moment, incurred God's favor and grace (mafdūl)."

(Brakke 2005, pp. 222-33) - Fighting demons, combatting them with selected verses of Scripture, is prominently demonstrated by his monastic handbook Antirrheticus, 'Talking Back', translated by David Brakke (2009), providing 498 passages of Scripture.

32 On the verse cf. (Gramlich 1983; Hartwig 2008, pp. 191-202).

33 (Reynolds 2006, p. 76). See for the textual problem underlying Romans 5:12 the ensuing footnote.

34 It is noteworthy that the grievous theologumenon of (inherited) "original sin", which owed its successful promulgation to the theology of the prominent Church father Augustine (354-430), had needed to be supported by textual 'manipulation'. It was Hieronymus (342-420), the authoritative translator of the Bible into Latin, who 'extracted' the idea of original sin from the already quoted Epistle to the Romans (Romans 5:12-17, especially verse 12) where it says "Wherefore, as by one man sin entered into the world, and death by sin; and so death passed upon all men, for that (eph' hô):all have sinned" He translated eph' hô as in quo, "in whom": propterea sicut per unum hominem in hunc mundum peccatum intravit et per peccatum mors et ita in omnes homines mors pertransiit in quo omnes peccaverun. By interpreting the Greek eph' hô as in quo Hieronymus connects the sin with Adam, an understanding that is not supported by the original Pauline text.

35 Translation: Augustine (1871).

36 Klaus von Stosch in Khorchide and Stosch (2019, p. 95) comments: “When the proclaimer of the Qur'an follows up [ ... ] by emphasizing that Jesus is Adam's equal in terms of his creation (see Q 3:59) and explains that he like Adam and unlike anyone else came into being through the immediate power of God's creative word, we find it hard to see this as a degradation of Jesus". This may hold true from an oecumenic comparative theology position; however, looking at the Qur'anic discourse itself we would regard this parallelization as a subtle polemic against the essential theological relation between the first and the second Adam in Christianity.

37 See e.g., Theophanes' (8th c.) Incarnation and the reversal of Adam's sin: The mythic Adam versus the God-man Adam (A hymn by Theophanes (6th c.) on the occasion of the Feast of the Annunciation):

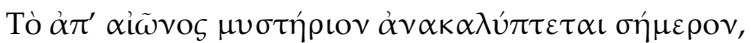

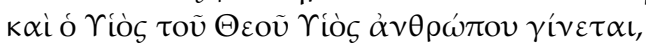

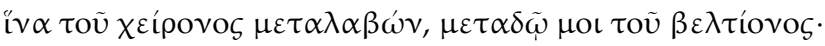

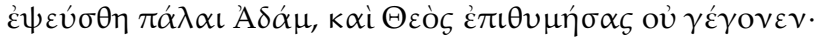

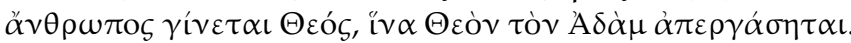




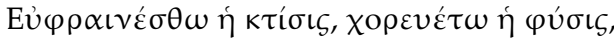

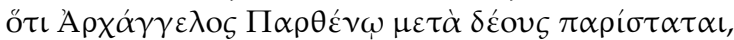

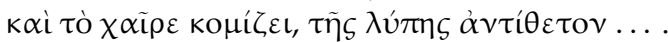

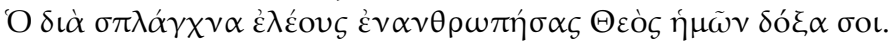

Today is revealed the mystery that is from all eternity:

the Son of God becomes the son of man, thus - sharing in what is worse, He may make man share in what is better.

In times of old, Adam was once deceived. He wanted to become God but received not his desire. Now God becomes man that He may make Adam God.

Let creation rejoice, let nature exalt: for the archangel stands in fear before the Virgin and saying to Her "Hail",

he brings the joyful greeting whereby our sorrow is assuaged.

O Thou that in thy merciful compassion was made man, our God, glory to Thee.

38 On this reading of Chrysostom cf. (Neuwirth 2017, p. 354).

39 On Satanic whispering see Larssons (2012, pp. 49-64).

40 (Mingana 1905, p. 167).

41 Contrary to that, the popular Targum Onqelos reads in agreement with the Hebrew: u-vera' YY Elohim yat Adam [ ... ], 'And Lord God created Adam [ ... ].

42 Cf. (Oberhänsli-Widmer 2007; Schechter 1909; Urbach 1975).

43 This human duality is already alluded to in Platon's Phaidros, pp. 246a-257a, where the human soul is compared to a chariot drawn by two winged steeds. "One of the steeds is "good and noble, and of good stock, while the other has the opposite character, and his stock is opposite." Lowry (1998, pp. 88-100, here p. 99), comments: "The good steeds is easily recognizable as a Hellenic version of "the image of God": he is "upright and clean-limbed, carrying his neck high ... a lover of glory, but with temperance and modesty ... and needs no whip, being driven by the word of command alone." The other is equally recognizable as the allegory of unruly instinct and passion: "crooked of frame, a massive jumble of a creature, ... hot-blooded, consorting with wantonness and vainglory; ... and hard to control with whip and goad." The first steeds strains to pull the chariot ever upward toward the good, but the second, with its unruly strength and hot-blooded wantonness, relentlessly pulls or pushes downward or off to the side". Cf. also (Oberhänsli-Widmer 2007, pp. 25-27). On the possible ways on transfer cf. (Boyarin 2007; Boyarin 2009).

$44 \quad$ See note 31

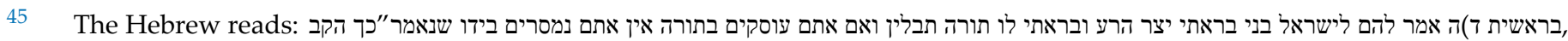

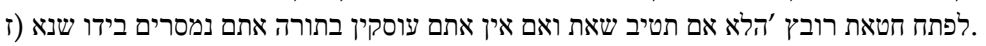

46 Exodus Rabba 32:1: Behold, I send an Angel [ . . . ] (Ex 23:20) - as it is written: I have said, Ye are gods [ ... ] (Ps 82:6). Had the Israelites patiently waited for Moses and had not committed that act (that is the Calf), there would have been no oppression, and the Angel of Death would not have reigned over them. For so it is said: [ ... ] And the writing was the writing of God, graven (harut) upon the tables (Ex 32:16). What does harut mean? R. Yehudah and R. Nehemyah (had different opinions): R. Yehudah said: freedom (herut) from opression, while R. Nehemyah said: freedom (herut) from the Angel of Death. At the time when Israel testified: [ . . . ] All that the Lord hath said will we do and be obedient (Ex 24:7), the Holy One blessed be He said: Adam, I have given only one commandment, and had he only kept it, I had made him like the serving angels, as it is written: [ ... ] behold, the man is become as one of us [ ... ] (Gen 3:22). For those, who do and keep 613 commandments - except the general and specific norms and subtilities -, would it not be just that they live and subsist in eternity? For it says: And from Mattanah to Nahaliel [ ... ] (Num 21:19); i.e., through the divine heritage they had obtained ever-lasting life. But when they said: [ ... ]. These by thy gods [ ... ] (Ex 32:8), death came above them. The Holy One blessed be He said: You walked in the footsteps of Adam, who could resist temptation of three hours; and in the ninth hour death was already imposed on them. I have said, Ye are gods, and you shall follow Adam - in his attributes: And ye shall die like Adam (Ps 82:7). What does it mean? And ye shall fall like one of the princes (Ps 82:7). R. Yehudah said: Be it like Adam, be it like Eve.

47 For a similar counter-narrative to the narrative of initial sin cf. (Cooper 2004).

48 Bloodshed - the Jewish origin is marked by the Hebraism yasfiku l-dima', see Gen 9:6: shofekh dam ha-adam damo yishshafekh ki beselem elohim 'asah et ha-adam, "Whoever sheds the blood of man, by man shall his blood be shed. For in His image did God make man." The Hebraism is the more telling as there is a second "shedding" of blood in a more technical sense, cf. Q 6:145. Bloodshed is already in the rabbinical tradition considered a cardinal sin, mentioned in Mishnah Avot 5:9, responsible for the destruction of the Temple in Jerusalem (compare bYoma 9b) and beginning exile: galut ba'a la-'olam 'al 'ovde 'avoda zara we-'al gilluy 'arayot we-'al shefikhut damim, 'Exile is caused in this world by idol worship, illicit sexual conduct and bloodshed'. All three cardinal sins are equally enumerated among the Noachide commandments (compare bSanhedrin 56a-b), underlining their universal quality. The wording yufsidu fih $\bar{a}$ is equally related to the cardinal sins, bringing about the corruption of the earth, cf. (Neuwirth and Hartwig 2021, pp. 102-10).

49 For an analysis of the historical/theological background cf. (Schäfer 2020). 
50 The notion of a divinely installed king is of course not reserved to the Davidic tradition. It has already been cherished in Iran, where the myth of Yima/ Gayōmard/Jamshīd had a formative bearing on the religious and political worldview (cf. Skjærvø 2012; Widengren 1959; Shaked 1987).

51 For more detailed background information cf. (Hartwig 2009, pp. 234-56; Hartwig 2013, pp. 297-319).

52 To mention the most important: (Sinai 2017, pp. 219-66; Reynolds 2006, pp. 230-27; Pregill 2020; Badawi 2014).

53 (Shoemaker 2018).

54 The assumption that Iblīs is the first who used qiyās -if not invented it-is found in a hadith attributed to Ja far al-Sādiq: (cf. al-Amīnī 2004, p. 91; cf. Stewart 2014, pp. 468-97, here: p. 482).

\section{References}

Abdel Haleem, Muhammad. 2010. The Qur'an. English Translation with Parallel Arabic Text. Oxford: Oxford University Press.

al-Amīnī, Muhammad Amīn. 2004. al-Imām Jáfar al-Sạdiq ramz al-hạậahah al-Islamiyyah. Beirut: Ma'́assasat al-Tārīkh al-'Arabī li-1Tibā'ah wa-1-Nashr wa-1-Tawzī' .

al-Azm, Sadik J. 1969. [Ṣạdiq Jalāl al-'Azmm], "Ma’sāt Iblīs". In Sạadiq Jalāl al- 'Azmm, Naqd al-fikr al-dīnī. Beirut: Dār al-Tạlī'a, pp. 99-132. al-Azm, Sadik J. 1991. The Importance of Being Earnest about Salman Rushdi. Die Welt des Islams 31: 1-49. [CrossRef]

al-Qādī, Wadād. 1988. The Term 'Khalīfa' in early Exegetical Literature. Die Welt des Islams 28: 392-411. [CrossRef]

al-Zahāwī, Jamīl Sịdqī. 1931. Thawra fī l-jahīm. al-Duhūr 1: 641-69.

Andrae, Tor. 1926. Der Ursprung des Islams und das Christentum. Uppsala: Almquist \& Wiksell.

Augustine. 1871. The City of God. Translated by Marcus Dods. 2 vols. Edinburgh: T \& T Clark.

Awn, Peter J. 1983. Satan's Tragedy and Redemption. Iblīs in Sufi Psychology. Leiden: Brill.

Badawi, Emran. 2014. The Qur'an and the Aramaic Gospel Tradition. New York and London: Routledge.

Becker, Adam H. 2016. The 'Evil Inclination' of the Jews. The Syriac Yatsra in Narsai's Metrical Homilies for Lent. Jewish Quarterly Review 106: 179-207. [CrossRef]

Boyarin, Daniel. 2007. Hellenism in Rabbinic Babylonia. In Cambridge Companium to Rabbinic Literature. Edited by Charlotte E. Fonrobert and Martin S. Jaffee. Cambridge: Cambridge University Press, pp. 336-63.

Boyarin, Daniel. 2009. Socrates and the Fat Rabbis. Chicago: University of Chicago Press.

Brakke, David. 2005. Making Public the Monastic Life: Reading the Self in Evagrius Ponticus' Talking Back. In Religion and the Self in Antiquity. Edited by David Brakke, Michael L. Satlow and Steven Weitzman. Bloomington: Indiana University Press, pp. $222-33$.

Brakke, David. 2009. Evagrius of Pontus, Talking Back-Antirrhêtikos. A Monastic Handbook for Combating Demons. Translated with an Introduction by David Brakke. Collegeville: Liturgical Press.

R. H. Charles, trans. 1913, The Apocrypha and Pseudepigrapha of the Old Testament in English, vol. II: Pseudepigrapha. Oxford: Clarendon Press.

Clarke, Elizabeth A. 1999. Reading Renunciation. Asceticism and Scripture in Early Christianity. Princeton: Princeton University Press.

Cooper, Alan. 2004. A Medieval Jewish Version of Original Sin. Ephraim of Luntshits on Leviticus 12. The Harvard Theological Review 97: 445-59. [CrossRef]

Donner, Fred McGraw. 2010. Muhammad and the Believers: At the Origins of Islam. Cambridge: Harvard University Press.

Flasch, Kurt. 2015. Der Teufel und seine Engel: Die neue Biographie. München: C.H. Beck.

Fowden, Garth, and Elizabeth Key Fowden. 2004. Studies in Hellenism, Christianity and the Umayyads. Athens: Research Centre for Greek and Roman Antiquity.

Geiger, Abraham. 1833. Was Hat Mohammed aus dem Judenthume Aufgenommen? Bonn: n.p.

Ghaffar, Zishan. 2020. Der Koran in Seinem Religions- und Weltgeschichtlichen Kontext. Eschatologie und Apokalyptik in den Mittelmekkanischen Suren. Paderborn: Ferdinand Schöningh.

Gramlich, Richard. 1983. Der Urvertrag in der Koranauslegung (zu Sure 7,172-173). Der Islam 60: 205-30. [CrossRef]

Greenblatt, Stephen. 2017. The Rise and Fall of Adam and Eve. The Story That Created Us. New York: W.W. Norton \& Company.

Grypeou, Emmanouela, and Helen Spurling. 2013. The Book of Genesis in Late Antiquity. Encounters between Jewish and Christian Exegesis. Leiden and Boston: Brill.

Haag, Herbert. 2000. Abschied vom Teufel, 2nd ed. Einsiedeln: Benzinger. First published 1969.

Haag, Herbert, ed. 1974. Teufelsglaube. Tübingen: Katzmann.

Hartwig, Dirk. 2008. Der 'Urvertrag' (Q 7:172). Ein rabbinischer Diskurs im Koran. In In vollem Licht der Geschichte”. Die Wissenschaft des Judentums und die Anfänge der kritischen Koranforschung. Edited by Dirk Hartwig, Walter Homolka, Michael J. Marx and Angelika Neuwirth. Würzburg: Ergon, pp. 191-202.

Hartwig, Dirk. 2009. Die “Wissenschaft des Judentums“ und die Anfänge kritischen Koranforschung. Perspektiven einer modernen Koranhermeneutik. Zeitschrift für Religions- und Geistesgeschichte 61: 234-56. [CrossRef]

Hartwig, Dirk. 2013. Die "Wissenschaft des Judentums" als Gründerdisziplin der kritischen Koranforschung: Abraham Geiger und die erste Generation jüdischer Koranforscher". In Jüdische Existenz in der Moderne: Abraham Geiger und die Wissenschaft des Judentums. Edited by Christian Wiese, Walter Homolka and Thomas Brechenmacher. Berlin: De Gruyter, pp. 297-319.

Horovitz, Josef. 1926. Koranische Untersuchungen. Berlin and Leipzig: W. de Gruyter.

Kaiser, Otto. 2000. Die alttestamentlichen Apokryphen. Eine Einleitung in Grundzügen. Gütersloh: Gütersloher Verlagshaus. 
Khorchide, Mouhanad, and Klaus von Stosch. 2019. The Other Prophet. Jesus in the Qur'an. Translated by Simon Pate. London: Gingko. Knittel, Thomas. 2002. Das griechische, Leben Adams und Evas'. Studien zu einer narrativen Anthropologie im frühen Judentum. Tübingen: Mohr-Siebeck.

Kugel, James L. 1997. The Bible as It Was. Cambridge, London and New Haven: Harvard University Press.

Larssons, Göran. 2012. The Sound of Satan: Different Aspects of Whispering in Islamic Theology. Temenos: Nordic Journal of Comparative Religion 48: 49-64. [CrossRef]

Lowry, Richard. 1998. The Dark Side of the Soul: Human Nature and the Problem of Evil in Jewish and Christian Traditions. Journal of Ecumenical Studies 35: 88-100.

Mingana, Alphonse, ed. 1905. Narsai doctrinis syri homiliae et carmina. Mosul: Fraternity of Preachers, vol. 1.

Minov, Sergey. 2015. Satan's Refusal to Worship Adam. A Jewish Motif and Its Reception in Syriac Christian Tradition. In Tradition, Transmission, and Transformation from Second Temple Literature through Judaism and Christianity in Late Antiquity. Edited by Menahem Kister, Hillel I. Newman, Michael Segal and Ruth A. Clements. Leiden: Brill, pp. 230-71.

Neuwirth, Angelika. 2010. Der Koran als Text der Spätantike. Ein europäischer Zugang. Frankfurt am Main: Verlag der Weltreligionen. Translated by Samuel Wilder. 2019. As the Qur'an and Late Antiquity. A Shared Heritage. New York and Oxford: Oxford University Press.

Neuwirth, Angelika. 2011. Frühmekkanische Suren: Poetische Prophetie. In Der Koran. Berlin: Verlag der Weltreligionen, vol. 1.

Neuwirth, Angelika. 2015. A Discovery of Evil in the Qur'an? Revisiting Qur'anic Versions of the Decalogue in the Context of Pagan Arab Late Antiquity. In Scripture, Poetry and the Making of a Community. Reading the Qur'an as a Literary Text. Edited by Angelika Neuwirth. Oxford: Oxford University Press, pp. 253-74.

Neuwirth, Angelika. 2017. Frühmittelmekkanische Suren: Das neue Gottesvolk: ‘Biblisierung des altarabischen Weltbildes, Handkommentar. In Der Koran. Berlin: Verlag der Weltreligionen, vol. 2/1.

Neuwirth, Angelika. 2020. David im Islam. Zur debatte-Sonderheft zu Ausgabe 1: 12-16.

Neuwirth, Angelika, and Dirk Hartwig. 2021. Spätmittelmekkanische Suren: Von Mekka nach Jerusalem. Der spirituelle Weg der Gemeinde heraus aus säkularer Indifferenz und apokalyptischen Pessimismus, Handkommentar. In Der Koran. Berlin: Verlag der Weltreligionen, vol. 2/2.

Nöldeke, Theodor. 1860. Geschichte des Qorāns. Göttingen: Dieterichsche Buchhandlung.

Nöldeke, Theodor, and Friedrich Schwally. 1909. Über den Ursprung des Qorāns. In Geschichtge des Qorāns. Leipzig: Dieterich, vol. 1. Oberhänsli-Widmer, Gabrielle. 2007. Der böse Trieb als rabbinisches Sinnbild des Bösen. Judaica 63: 18-43.

Pagels, Elaine. 1991. Adam, Eve, and the Serpent. New York: Random House.

Pagels, Elaine. 1995. The Origins of Satan. How Christians Demonized Jews, Pagans, and Heretics. New York: Vintage Books.

Pregill, Michael E. 2020. The Golden Calf between Bible and Qur'an. Scripture, Polemic, and Exegesis from Late Antiquity to Islam. New York and Oxford: Oxford University Press.

Reynolds, Gabriel S. 2006. Redeeming the Adam of the Qur'ān. In Arabische Christen-Christen in Arabien. Edited by Detlev Kreikenbom, Franz-Christoph Muth and Jörn Tielmann. Frankfurt am Main: Lang, pp. 71-83.

Reynolds, Gabriel S. 2010. The Qur'ān and Its Biblical Subtext. London and New York: Routledge, pp. 39-54.

$\mathrm{Ri}$, Andreas Su-Min. 1987. La Caverne des trésors: Les deux recensions syriaques (Corpus Scriptorum Cristianorum Orientalium 486, Scriptores Syriaci 207). Louvain: Peeters Publishers.

Rost, Leonhard. 1985. Einleitung in die alttestamentlichen Apokryphen und Pseudepigraphen einschließlich der großen Qumran-Handschriften, 3rd ed. Heidelberg and Wiesbaden: Quelle und Meyer.

Saint Ephrem. 1990. Hymns on Paradise. Introduction and Translation. Edited by Sebastian Brock. Crestwood: St Vladimir's Seminary Press.

Schäfer, Peter. 1975. Rivalität zwischen Engeln und Menschen. Untersuchungen zur rabbinischen Engelvorstellung. Berlin and Boston: De Gruyter.

Schäfer, Peter. 2020. Two Gods in Heaven. Jewish Concepts of God in Antiquity. Princeton: Princeton University Press.

Schechter, Solomon. 1909. Some Aspects of Rabbinic Theology. London: Adam and Charles Black.

Schmid, Nora K., Nora Schmidt, and Angelika Neuwirth, eds. 2016. Denkraum Spätantike. Reflexionen von Antiken im Umfeld des Koran. Wiesbaden: Harrassowitz.

Shaked, Shaul. 1987. First Man, First King: Notes on the Semitic-Iranian Syncretism and Iranian Mythological Transformation. In Gilgul: Essays on Transformation, Revolution and Permanence in the History of Religions. Edited by Shaul Shaked, David Schulman and Guy G. Stroumsa. Leiden and New York: Brill, pp. 238-56.

Shoemaker, Stephen J. 2018. The Apocalypse of Empire. Imperial Eschatology in Late Antiquity and Early Islam. Philadelphia: University of Pennsylvania Press.

Sievers, Mira. 2019. Schöpfung zwischen Koran und Kalām. Ansätze einer koranischen Theologie. Berlin: EBVerlag.

Sinai, Nicolai. 2017. The Eschatological Kerygma of the Early Qur'an. In Apocalypticism and Eschatology in Late Antiquity: Encounters in the Abrahamic Religions, 6th-8th Centuries. Edited by Hagit Amirav, Emmanouela Grypeou and Guy Stroumsa. Leuven: Peeters, pp. 219-66.

Skjærvø, Oktor. 2012. Jamšid i, Myth of Jamšid. Encyclopaedia Iranica 14: 501-22.

Speyer, Heinrich. 1931. Die biblischen Erzählungen im Qoran. Gräfenhainichen: C. Schulze.

Stefanides, Emmanuelle. 2008. The Qur'an Made Linear. A Study of the Geschichte des Qorāns' Chronological Reordering. Journal of Qur'anic Studies 10: 1-22. [CrossRef] 
Steppat, Fritz. 1989. God's Deputy. Materials on Islam's Image of Man. Arabica 36: 163-72. [CrossRef]

Stewart, Devin J. 2014. An Eleventh-Century Justification of the Authority of Twelver Shiite Jurists. In Islamic Cultures, Islamic Contexts. Essays in Honor of Professor Patricia Crone. Edited by Asad Q. Ahmes, Behnam Sadeghi, Robert G. Hoyland and Adam Silverstein. $\backslash$ Leiden and Boston: Brill, pp. 468-97.

Toepel, Alexander. 2013. The Cave of Treasures. A New Translation and Introduction. In Old Testament Pseudepigrapha. More Noncanonical Scriptures. Edited by Alexander Panayotov, James R. Davila and Richard Bauckham. Grand Rapids: William B, vol. 1. Urbach, Efraim E. 1975. The Sages. Their Concepts and Beliefs. Jerusalem: Magnes Press, 2 vols.

Utley, Francis L. 1945. The Bible of the Folk. California Folklore Quarterly 4: 1-17. [CrossRef]

van Leeuwen, Richard. 2015. Literature and Religious Controversy. The Vision of Hell in Jamīl Sịdqī al-Zahāwī's Thawra fī l-jahīm. In Locating Hell in Islamic Traditions. Edited by Christian Lange. Leiden: Brill, pp. 336-51.

Widengren, Geo. 1959. The Sacral Kingship of Iran. In Contributions to the Central Theme of the VIIIth International Congress for the History of Religions (Rome, April 1955). Edited by Carl-Martin Edsman. Leiden and New York: Brill, pp. 242-57.

Yerushalmi, Yosef Hayim. 1996. Zakhor. Jewish History and Jewish Memory. Foreword by Harold Bloom. Seattle: University of Washington Press.

Zellentin, Holger. 2017. Trialogical Anthropology: The Qur'an on Adam and Iblis in View of Rabbinic and Christian Discourse. In The Quest for Humanity - Contemporary Approaches to Human Dignity in the Context of the Qur'anic Anthropology. Edited by Rüdiger Braun and Hüseyin Çiçek. Newcastle: Cambridge Scholars Publishing, pp. 54-125. 